\title{
Chromatin Switches during Neural Cell Differentiation and Their Dysregulation by Prenatal Alcohol Exposure
}

\author{
David P. Gavin ${ }^{1,2, *}$, Dennis R. Grayson ${ }^{2}$, Sajoy P. Varghese ${ }^{1}$ and Marina Guizzetti ${ }^{3,4, *}$ \\ 1 Jesse Brown Veterans Affairs Medical Center, 820 South Damen Avenue (M/C 151), Chicago, IL 60612, USA; \\ sajoy.varghese@va.gov \\ 2 Center for Alcohol Research in Epigenetics, Department of Psychiatry, University of Illinois at Chicago, \\ 1601 W. Taylor St., Chicago, IL 60612, USA; dgrayson@psych.uic.edu \\ 3 Department of Behavioral Neuroscience, Oregon Health \& Science University, \\ 3181 SW Sam Jackson Park Road L470, Portland, OR 97239, USA \\ 4 Veterans Affairs Portland Health Care System, 3710 Southwest US Veterans Hospital Road, \\ Portland, OR 97239, USA \\ * Correspondence: dgavin@psych.uic.edu (D.P.G.); guizzett@ohsu.edu (M.G.); Tel.: +1-312-569-7422 (D.P.G.); \\ +1-503-220-8262 (ext. 58618) (M.G.); Fax: +1-312-569-8114 (D.P.G.); +1-503-273-5351 (M.G.)
}

Academic Editor: Roel Ophoff

Received: 31 January 2017; Accepted: 6 May 2017; Published: 11 May 2017

\begin{abstract}
Prenatal alcohol exposure causes persistent neuropsychiatric deficits included under the term fetal alcohol spectrum disorders (FASD). Cellular identity emerges from a cascade of intrinsic and extrinsic (involving cell-cell interactions and signaling) processes that are partially initiated and maintained through changes in chromatin structure. Prenatal alcohol exposure influences neuronal and astrocyte development, permanently altering brain connectivity. Prenatal alcohol exposure also alters chromatin structure through histone and DNA modifications. However, the data linking alcohol-induced differentiation changes with developmental alterations in chromatin structure remain to be elucidated. In the first part of this review, we discuss the sequence of chromatin structural changes involved in neural cell differentiation during normal development. We then discuss the effects of prenatal alcohol on developmental histone modifications and DNA methylation in the context of neurogenesis and astrogliogenesis. We attempt to synthesize the developmental literature with the FASD literature, proposing that alcohol-induced changes to chromatin structure account for altered neurogenesis and astrogliogenesis as well as altered neuron and astrocyte differentiation. Together these changes may contribute to the cognitive and behavioral abnormalities in FASD. Future studies using standardized alcohol exposure paradigms at specific developmental stages will advance the understanding of how chromatin structural changes impact neural cell fate and maturation in FASD.
\end{abstract}

Keywords: histone modifications; DNA methylation; fetal alcohol; neural cell differentiation; neurons; astrocytes; chromatin

\section{Introduction}

A missing link in the study of fetal alcohol spectrum disorders (FASD) is whether the effects of prenatal alcohol exposure on neural cell fate are attributable to the effects of alcohol on chromatin [1]. Neural cell differentiation (neuroepithelial cells to radial glia, and radial glia to neurons and macroglia (astrocytes and oligodendrocytes)) is dependent upon extracellular cues received by developing cells, and whether the cells receiving these signals are able to respond by changing their transcriptional profiles [2-4]. Transcriptional control of the production of many of these extracellular signaling proteins, as well as the transcriptional responses of the targeted cells, is partly dependent upon chromatin architecture [5-7]. Recent studies indicate that prenatal alcohol exposure affects neural cell differentiation, 
maturation, and chromatin architecture. However, how the chromatin structural changes observed in FASD models mediate altered neural cell development have yet to be fully elucidated.

The overall scope of this review article is to discuss epigenetic changes that occur during normal neurodevelopment, and the impact of prenatal alcohol exposure on chromatin structure in relation to neural cell fate and maturation. We particularly emphasize future research directions that will lead to a better understanding of the relationship between alcohol-induced chromatin modifications, neural cell fate determination, cell maturation, and FASD.

\section{Chromatin Structure and Gene Expression}

The definition of "epigenetics" has gone through several etymological stages. In the 1940s, Waddington originally defined epigenetics as "the branch of biology which studies the causal interactions between genes and their products which bring the phenotype into being" [8]. In other words, Waddington's definition of epigenetics referred to the combined effects of genotype and gene expression on phenotype. In 1958, David Nanney used the term to mean inherited phenomena not explained by conventional genetics [9]. To this day, a consensus regarding the definition of epigenetics remains elusive. The broadest definition includes any factors that affect gene transcription, such as noncoding RNAs, repressor proteins, histone modifications, etc. [10,11], while the narrower definition includes only DNA modifications and perhaps a few histone protein post-translational modifications (PTMs) that propagate following cell division [12-14]. We do not take a position on whether a broad or narrow definition of epigenetics is more appropriate. In the current review, we use the term to refer to histone protein PTMs and DNA modifications.

Any mediator of long-lasting changes in cell fate must have a high degree of stability. DNA methylation is mitotically and meiotically heritable and has no requirement for turnover in non-dividing cells, such as most neurons and astrocytes $[15,16]$. Histone proteins have a half-life of months, and there is evidence that, for example, H3K4 and H3K27 methylation are mitotically inherited [13,17]. Histone and DNA methylation are therefore plausible candidates for participating in the lifelong manifestations of FASD. Some histone acetylation marks have a half-life that is only minutes long [12]. This makes acetylation a poor candidate to be responsible for enduring illnesses such as FASD. Acetylation is included in this discussion because it is a marker of chromatin structure, and is tightly correlated with more stable and longer-lasting marks, such as H3K4 methylation and DNA methylation [18]. While non-coding RNAs, including microRNAs, modulate signaling pathways involved in cell fate determination and brain development and are altered by ethanol, they are relatively short-lived. The effects of alcohol on non-coding RNA are reviewed elsewhere [19]. This review focuses on the more stable epigenetic mediators that directly affect chromatin conformation through histone modifications and DNA methylation.

Chromatin structure does not dictate transcriptional activity; rather, the evidence suggests that it increases or decreases the accessibility of transcription factors to DNA [20]. Restrictive chromatin prevents transcription by barring transcription factors and RNA polymerases access to DNA. Conversely, less restrictive chromatin allows gene expression to occur. Histone PTMS can be broadly categorized as being associated with less or more restrictive chromatin. Histone $\mathrm{H} 3$ and $\mathrm{H} 4$ lysine acetylation and $\mathrm{H} 3$ lysine 4 methylation $(\mathrm{H} 3 \mathrm{~K} 4 \mathrm{me} / 3)$ are usually associated with a transcriptionally permissive chromatin structure [21], while dimethylated $\mathrm{H} 3$ lysine 9 (H3K9me2) and di- and trimethylated $\mathrm{H} 3$ lysine 27 (H3K27me2/3) are associated with lower levels of gene expression.

The enzymes and attendant proteins that regulate histone acetylation and H3K4 methylation are important factors for maintaining these PTMs and their effects on transcription. Histone $\mathrm{H} 3$ and $\mathrm{H} 4$ acetylation is catalyzed by histone acetyltransferases (HATs), including cAMP response element-binding protein binding protein (CREBBP) and E1A binding protein p300 (EP300). Histone deacetylases (HDACs) remove this PTM [22]. H3K4 methylation is catalyzed by lysine methyltransferase-2A (KMT2A), ASH1L, and SET Domain Containing Lysine Methyltransferase (SETD7), among others. This mark is erased by the lysine demethylases Lysine Demethylase 1A (KDM1A), KDM1B, and KDM5D. 
The enzymes that add and subtract histone marks associated with transcriptional repression, such as H3K9me2 and H3K27me3, are also important in regulating gene expression. Euchromatic Histone-Lysine N-Methyltransferase-1 (EHMT1), EHMT2, and SET Domain Bifurcated 1 (SETDB1) enzymes catalyze H3K9 methylation [23]. H3K27 methylation is catalyzed by the Polycomb Repressive Complex 2 (PRC2), which is comprised of Embryonic Ectoderm Development (EED), Enhancer of Zeste 1 (EZH1), and EZH2, among others [24]. Following H3K27 methylation, PRC1, which contains Ring finger protein 1 (RING1) and Ring finger protein 2 (RNF2), among others, is recruited where it participates in forming heterochromatin [25]. Together PRC1 and 2 are termed Polycomb Group (PcG) proteins.

Methylated cytosine nucleotides (5-methylcytosine $(5 \mathrm{mC})$ ) are also often components of heterochromatin. $5 \mathrm{mC}$ can be further modified through the successive oxidation of the methyl group forming hydroxymethyl, formyl, or carboxyl groups [26]. This review focuses on the best-characterized and most abundant DNA modifications in the brain, $5 \mathrm{mC}$ and 5-hydroxymethylcytosine (5hmC). $5 \mathrm{mC}$ is catalyzed by members of the DNA methyltransferase family of enzymes; DNMT1, 3A, and $3 \mathrm{~B}$ [27]. Generally, $5 \mathrm{mC}$ is associated with lower transcriptional activity. On the other hand, there are reports of a positive correlation between gene expression and gene-body $5 \mathrm{mC}$ levels [28], including at neuronal genes [29]. 5mC serves as a ligand for methyl-CpG-binding domain proteins (MBD), including $\mathrm{MeCP} 2$ [30]. $5 \mathrm{mC}$ is stable, but can be converted to $5 \mathrm{hmC}$ by Ten-eleven Translocation (TET) enzymes [31]. Several studies indicate that $5 \mathrm{hmC}$ is a necessary intermediary step between $5 \mathrm{mC}$ and nonmethylated cytosines as part of a base excision repair DNA demethylation process [32]. $5 \mathrm{hmC}$ within gene bodies in the brain is generally associated with active transcription, while when it is located within promoter regions it is associated with decreased gene expression [33-39]. More recently, $5 \mathrm{hmC}$ has been reported as the predominant modification located within enhancers poised for activation [28]. Overall, however, the association between $5 \mathrm{hmC}$ levels and gene expression in the brain is not entirely clear. This suggests that $5 \mathrm{hmC}$ may serve additional functions, such as influencing RNA splice choices [40].

Traditionally it was believed that cytosine bases could only be methylated when they preceded guanine bases $(\mathrm{CpG})$. However, recently it was demonstrated that methylated $\mathrm{CpHs}$ (where $\mathrm{H}$ is not guanine) may be equal in number to methylated CpGs, specifically in the brain [39]. Methylation of $\mathrm{CpH}$ is catalyzed by DNMT3A and serves as a ligand for MeCP2 binding [41].

\section{The Pluripotency/Neurogenesis Switch}

Chromatin structure plays an important role in maintaining pluripotency prior to cellular differentiation and attainment of a neural cell fate. This occurs through maintaining the continued expression of stemness genes such as POU domain, class 5, transcription factor 1 (Pou5f1), Nanog, and SRY (sex determining region Y)-box 2 (Sox2) [42-44]. These stemness genes participate in preventing the premature expression of neural genes. Independent of these factors, H3K27 methylation also prevents the premature differentiation of pluripotent cells.

Pluripotency is associated with higher H3K4 methylation and histone acetylation levels globally, and at specific stemness gene promoters [45-47]. The transcription factor Pouff1 appears to be particularly sensitive to fluctuations in histone modifications. Increased Pouff1 expression in induced pluripotent cells is associated with high H3K4me2 and histone acetylation and low H3K9me2 at its promoter. Interestingly, in these cells neuronal development genes, Neurofilament, Medium Polypeptide (Nefm) and Thymus cell antigen 1, theta (Thy1) also acquire higher amounts of H3K4me2 and histone acetylation, but with no concomitant increase in their expression [48]. A possible explanation is that the transcriptional activity of certain genes, such as Pou5f1, may be more sensitive to changes in chromatin structure than other genes. In support of this hypothesis, several studies demonstrate a particularly close association between low DNA methylation, high histone acetylation, high histone arginine methylation, and high Pou5f1 expression [49-51].

POU5F1 and NANOG are in part responsible for suppressing the premature expression of neuronal genes in pluripotent cells by increasing RE1-silencing transcription factor (REST) expression [52,53]. REST maintains neuronal genes in a quiescent state through its ability to coordinate 
a process leading to condensed chromatin at specific promoters. It accomplishes this in association with co-factors, such as REST Co-repressor (RCOR) and SIN3A, as well as the chromatin modifying enzymes, HDAC1 and 2, KDM1A and EHMT1/2, and EHMT2-associated adaptor proteins [54-59].

A different set of neuronal genes from those silenced by REST are repressed by H3K27 methylation [59-62]. In fact, the factor(s) responsible for recruiting PcG to specific neuronal gene regulatory regions have not yet been discovered. Thus, the combined effects of REST and PcG protein-coordinated repressor complexes at neuronal gene promoters maintain the pluripotency/neurogenesis switch to a position that favors pluripotency and prevents neural cell differentiation.

After cells attain a neural cell fate, high global H3K27me3 and low global H3K4 methylation repress neuronal differentiation [63,64]. Deletion of the PRC2 component $E z h 2$ in the cortex at the onset of neurogenesis, embryonic day (E9.5) in the mouse, results in increased production of cortical neurons by E14 but decreased numbers of neurons at birth [65]. Also, increased expression of the H3K27 demethylase, lysine (K)-specific demethylase 6B (KDM6B), allows for the expression of neurogenesis promoting genes, such as the $\gamma$-aminobutyric acid (GABA) ergic neuronal development promoting gene Distal-less homeobox 2 (Dlx2) [63,64]. H3K4 methyltransferase KMT2A expression is also necessary for Dlx2 expression and neurogenesis during development [66]. Thus, any insult that would induce high H3K27 methylation and reduce H3K4 methylation during this period of brain development might suppress neurogenesis and prolong pluripotency.

Based on these reports, pluripotency is maintained prior to neural cell differentiation by the expression of certain stemness proteins that are regulated by changes in chromatin structure. On the other hand, stemness proteins, such as POU5F1 and NANOG, in coordination with REST, recruit the gene silencing chromatin machinery to neuronal genes, preventing premature differentiation. Independent of REST, H3K27 methylation also prevents premature neuronal gene expression by targeting a separate set of neuronal gene promoters.

\section{The Neurogenesis/Gliogenesis Switch}

During brain development, astrocytes interact with neurons via membrane-bound and soluble factors, providing instructions to neurons leading to neurite outgrowth/dendritic arborization and synaptogenesis $[67,68]$. In the adult brain, astrocytes regulate many functions; for example, astrocytes reuptake neurotransmitters and $\mathrm{K}+$ at the end of action potentials, provide neurons with substrates for the biosynthesis of neurotransmitters and glucose, control cerebral blood flow, and are involved in the modulation of synaptic transmission by releasing gliotransmitters $[69,70]$.

Pro-astrogliogenesis gene promoters are silenced during the neurogenic phase in part by higher levels of DNA methylation, MeCP2 promoter binding, and promoter H3K9me2, as well as lower levels of transcriptionally facilitative histone modifications, such as $\mathrm{H} 3 \mathrm{~K} 4 \mathrm{me} 2 / 3$, acetylated lysine 9 of histone H3 (H3K9ac), and acetylated lysine 14 of histone H3 (H3K14ac) [5,71,72].

Histone acetylation plays an important role in the transition from the neurogenic to gliogenic phase of neural cell development. The pro-neuronal transcription factor, Neurogenin 1 (NEUROG1), prevents Phosphorylated Signal Transducer and Activator of Transcription (pSTAT) from activating glial gene transcription by sequestering EP300/CREBBP, a transcription factor with HAT activity, from glia specific promoters [73]. Similarly, global increases in HDAC inhibitor mediated-histone acetylation increase astrogliogenesis and suppress neurogenesis in the E13.5-15.5 ganglionic eminence in astrocyte cultures from postnatal day 2 (P2) rats, and in rats treated from P2 to P4 in the cortex [74,75]. On the other hand, HDAC inhibition in neural stem cells in the E13.5-15.5 cortex and in the adult hippocampus increases the total number of neurons while actively suppressing astrocyte differentiation [75-78]. One of the genes induced by HDAC inhibitors is the neurotrophic growth factor Brain-Derived Neurotrophic Factor (Bdnf), itself an inhibitor of gliogenesis $[79,80]$. HDAC inhibition also mediates decreases in Glial fibrillary acidic protein (GFAP) expression in primary human astrocytes and in astrocytoma cells [81]. Taken together, it appears possible that the effects of histone acetylation on neuronal vs. astrocyte differentiation depend upon the developmental stage. Histone acetylation appears to amplify ongoing cellular processes, such 
that increasing histone acetylation promotes neuronal production and inhibits gliogenesis during a period of neurogenesis, while during astrogliogenesis it amplifies the expansion of this cell type.

Histone methylation is also important for the neuronal-glial switch. $\mathrm{H} 3 \mathrm{~K} 9 \mathrm{me} 3$ and trimethylated lysine 36 of histone 3 (H3K36me3) demethylase Lysine Demethylase 4A (KDM4A) forms a complex with the transcriptional repressor of glial cell differentiation, Nuclear receptor co-repressor (NCOR) [82]. Knockdown of KDM4A leads to a decrease in neuronal differentiation and an increase in astrocytes due to a lack of H3K9me3 demethylation at the Bdnf promoter and an increase in H3K36me3 at the Gfap promoter [83]. Maintaining low levels of PcG proteins, such as RNF2, EED, and EZH2, is also important for promoting neurogenesis [84-86]. In vivo knockout of Rnf2 (a component of the repressive complex PRC1 that mediates the ubiquitination of lysine 119 of histone H2A (H2AK119)) beginning at E13.5 or Ezh2 (the lysine methyltransferase that trimethylates $\mathrm{H} 3 \mathrm{~K} 27$ in the repressive PRC2 complex) at E12.5 prolong the neurogenic phase, at the expense of astrogliogenesis [65,84]. Rnf2 knockouts continue to have increased numbers of cortical neurons as late as P6.5 [84]. These studies indicate that a reduction in H3K27me3 promotes neurogenesis at the expense of astrogliogenesis during the neurogenic/gliogenic switch.

As opposed to H3K27me3, decreases in DNA methylation promote astrogliogenesis at the expense of neurogenesis. Genetic knockdown or pharmacological inhibition of DNMT1 or DNMT3A leads to global DNA hypomethylation in the developing central nervous system and precocious astrogliogenesis at the expense of neurogenesis $[72,87,88]$. Similarly, a $\mathrm{MeCP} 2$ loss of function mutation increases neural cell astrocyte production compared with wild-type MeCP2-expressing cells [89].

Based on these data, it appears that prior to the time the neurogenic/gliogenic switch is normally engaged, low histone acetylation and H3K27 methylation and high DNA methylation prevent gliogenesis. Studies demonstrate that genetic or pharmacological approaches that increase overall histone acetylation and H3K27 methylation promote gliogenesis in the E13.5-15.5 brain, and knockdown of DNA methyltransferases or methyl DNA binding proteins from conception or early in development promotes gliogenesis.

The switch from the neurogenic to the gliogenic phase normally takes place between E18.5 and E19.0 in the rodent neocortex [85]. The first step in this process occurs through the expression of NOTCH ligands, such as the Delta-like (DLL) proteins, by young neurons [90]. Neuronally expressed NOTCH ligands bind NOTCH receptors on astrocyte-fated cells, leading to the activation of NOTCH signaling [90]. NOTCH activation promotes the expression of the transcription factor Nuclear factor I A (NFIA), which participates in the DNA demethylation of astrogliogenesis promoting genes such as Gfap, S100 protein, beta polypeptide (S100b), and aquaporin genes [90]. DNA demethylation primes astrogliogenesis genes for the second step of this process, transcriptional activation by extracellularly released pro-astrogliogenic cytokines, such as leukemia inhibitory factor (LIF) [71]. Pro-astrogliogenic cytokines activate the Janus Kinase/Signal Transducer and Activator of Transcription (JAK-STAT) signaling pathway [71]. Activated NOTCH and basic helix-loop-helix (bHLH) proteins, such as Hairy and Enhancer of Split (HES), together with pro-astrogliogenic cytokines, promote STAT phosphorylation. Phosphorylated STAT (pSTAT) is able to bind the pro-astrogliogenesis gene promoters that are demethylated in the first step of this process leading to increased gene expression [71]. Bone Morphogenetic Proteins (BMPs) also promote astrogliogenesis in part by inducing histone acetylation of pro-glial promoters, facilitating their expression [91].

Following the neurogenic to gliogenic switch, DNA methylation and methylated DNA-histone complexes also play a role in astrocyte maturation, as suggested by the fact that either the knockdown of DNMT1 or the presence of a MeCP2 mutation hastens astrocytes to attain a more fully mature state $[72,89]$. Precociously differentiated astrocytes from $\mathrm{MeCP} 2$ mutant mice fail to support the normal dendritic arborization of neurons containing wild-type MeCP2 [92-94].

These studies indicate that the timing of the switch from neurogenesis to astrogliogenesis is tightly regulated by a series of epigenetic events. Prior to astrogliogenesis, high DNA methylation, MeCP2 binding to methylated DNA, and low H3K27 methylation, prevent the premature activation of glial cell gene expression. At E18-19 in the rodent neocortex, young neurons express NOTCH, which activates a cascade of events leading to DNA demethylation and increased histone acetylation of glial genes, facilitating their expression. After astrogliogenesis begins, DNA methylation and $\mathrm{MeCP} 2$ continue to 
play important roles in preventing precocious maturation of astrocytes. An environmental stimulus, such as alcohol, that could perturb these epigenetic events would therefore likely lead to abnormal differentiation or maturation of neurons and astrocytes (Figure 1).

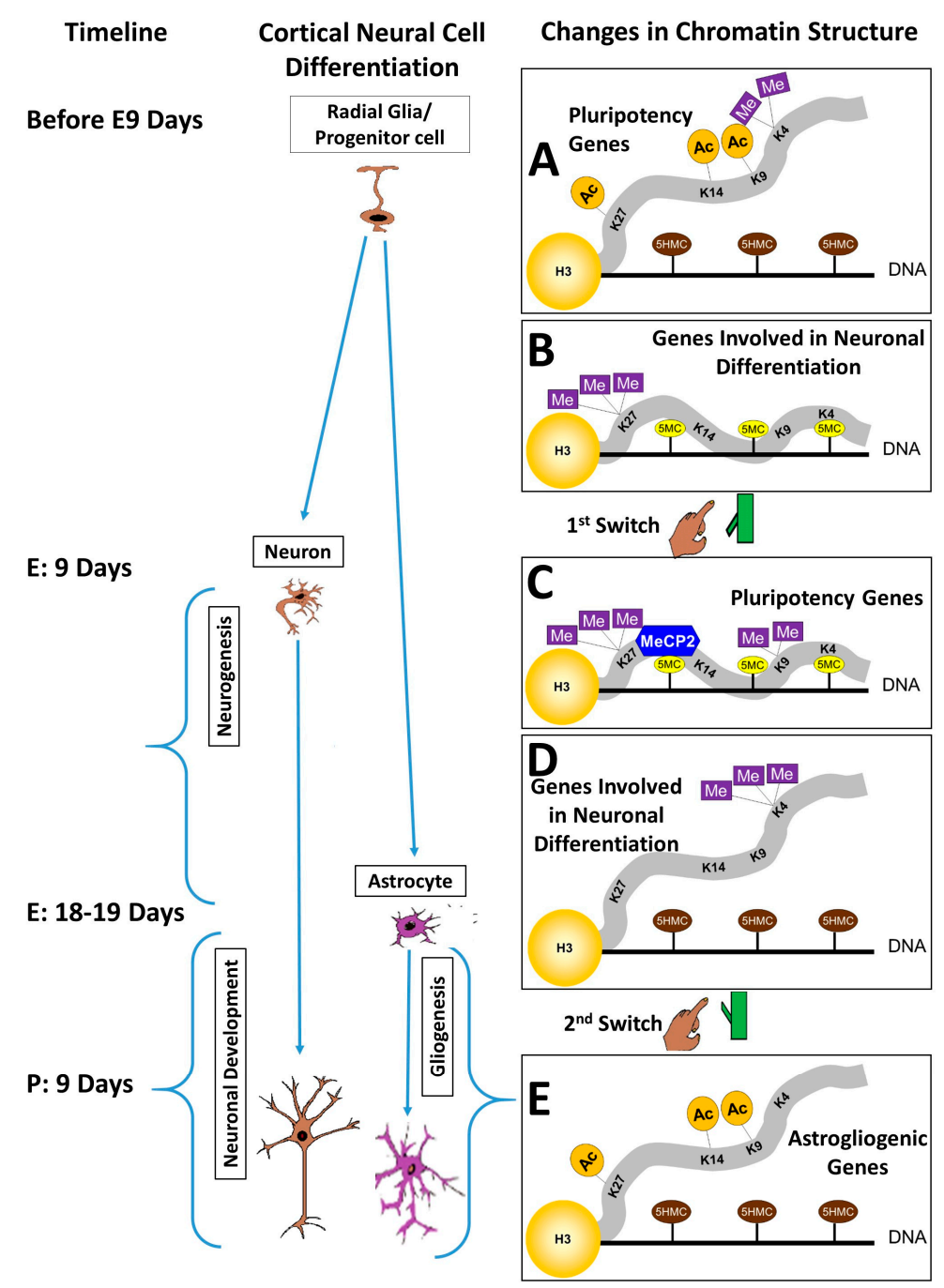

Figure 1. Cortical neural cell development and changes in chromatin structure. (A) Prior to embryonic day (E) nine neural precursor cells are in an undifferentiated state that is maintained by a combination of histone acetylation and histone lysine 4 (H3K4) methylation associated with increased gene expression of pluripotency genes, such as Pouff1 and Nanog; (B) repressive histone modifications, such as histone 3 lysine 27 methylation (H3K27me2/3) and DNA methylation (5-methylcytosine (5mC)) prevent expression of genes that would lead to neuronal differentiation such as high-mobility group A (HMGA) family of DNA-binding proteins and Dlx homeobox genes; (C) at approximately E9, a chromatin regulation switch is flipped between pluripotency to a neurogenic phase of brain development. Pluripotency gene promoters are switched off by restrictive histone modifications, DNA methylation, and the methyl-CpG binding domain protein $\mathrm{MeCP} 2$ binding to $5 \mathrm{mC}$; (D) Neurogenic genes are turned on through the removal of methyl groups from H3K27, the addition of methyl groups to lysine 4 of $\mathrm{H} 3$ (H3K4me2/3), and the conversion of repressive $5 \mathrm{mC}$ to 5-hydroxymethylcytosine $(5 \mathrm{hmC}) ;(\mathrm{E})$ at approximately E18-19 in the neocortex, the chromatin regulation switch is flipped once again, this time turning off neurogenic genes in neural cell precursors and turning on astrogliogenic genes. Histone acetylation and DNA demethylation turns on astrogliogenesis. By postnatal day (P) 7 most neurons have reached their final location in the neocortex, while gliogenesis continues. Orange: histone acetylation; purple: histone methylation; blue: proteins binding DNA; yellow: DNA methylation; brown: DNA 5-hydroxymethylation. 


\section{Abnormal Differentiation in FASD}

Alcohol can profoundly perturb the well-orchestrated events that determine the number, distribution, morphology, and functioning of neurons and astrocytes. Low doses of alcohol have been shown to promote stem cell expansion, while higher concentrations slow proliferation [95-99]. Several cell culture studies indicate that alcohol exposure inhibits neurogenesis [100], while hastening neuronal differentiation $[100,101]$. During the neurogenic period, alcohol causes a decrease in a variety of neuronal populations including hippocampal CA1 pyramidal cells [102-111], cerebellar Purkinje cells [112-115], and cerebral cortical neurons [116,117]. These effects may be caused by both a disruption of neuronal generation when exposure occurs earlier in gestation, and neuronal apoptosis when exposure occurs later in gestation during defined sensitive periods [103,116,118-122].

Alcohol also differentially affects specific neuronal populations. Several studies indicate that prenatal alcohol reduces the density and functioning of GABA neurons [123-128], and increases glutamatergic neurons [100]. These changes may be related to alcohol induction of pro-glutamatergic genes, such as Paired box 6 (Pax6), Neurogenin 2 (Neurog2), and Neurogenic Differentiation-1 (Neurod1) and inhibition of pro-GABAergic Mammalian Achaete Scute Homolog-1 (Ascl1) levels [100]. Additionally, prenatal alcohol exposure alters the distribution and morphology of neurons [101,129]. Ectopic distribution and density of neuronal synapses generated late in gestation have been reported [116,130-134].

In cell culture experiments, short-term ( $48 \mathrm{~h}$ ) alcohol treatment of neural stem cells (NSC) decreases the size of astrocytes, but long-term treatment (eight days) increases their size [134]. In astrocytoma cell cultures, $24 \mathrm{~h}$ alcohol treatment decreases glial cell proliferation [135]. In vivo, prenatal alcohol exposure also decreases glial growth and proliferation and GFAP expression [136,137]. However, neonatal alcohol exposure increases GFAP expression [138-141].

Based on these reports, it is clear that ethanol alters both neuronal and astrocyte differentiation and maturation. Prior to the neurogenesis phase of neural cell development, ethanol causes premature neuronal differentiation, but exposure during the neurogenesis phase induces neuronal apoptosis. Additionally, ethanol alters the neuronal cell types produced, with increased numbers of glutamatergic neurons and fewer GABAergic neurons. Further, ethanol alters the morphology of neuronal processes. Finally, in utero ethanol exposure also affects astrocyte development. Ethanol reduces glial cell growth and proliferation. Overall, it appears that ethanol has profound effects on neural cell differentiation and maturation. However, the underlying molecular mechanisms alcohol disrupts remain to be fully established.

\section{FASD, Cell Fate, and Chromatin Structure}

The coordinated chromatin remodeling events that lead to the neuroepithelial cell lineage and ultimately to neuron and astrocyte generation are acutely sensitive to alcohol. Over the last decade, alcohol-mediated effects on DNA methylation and histone modifications have been increasingly characterized in cell, animal, and clinical reports. Studies have begun investigating the effects of alcohol-induced histone modifications, specifically regarding their roles in differentiation. One challenge in determining the effects of alcohol on neural cell development is the variations that occur due to differences in dose and time of exposure in different studies. For example, Veazey et al. measured acute alcohol-induced changes in multiple histone modifications across 22 gene promoters in NSCs. They reported different effects on H3K4me3, H3K9ac, H3K9me2, and H3K27me3 levels depending on alcohol dose $(160 \mathrm{mg} / \mathrm{dL}$ vs. $320 \mathrm{mg} / \mathrm{dL})$, and whether alcohol was present at the time of culture harvest vs. four days following alcohol exposure [142]. The impact of alcohol on the expression and function of chromatin regulators may also shift considerably with age. Early gestational alcohol exposure produces different effects than alcohol exposure during the equivalent of the third human trimester (which, in rodents, corresponds to the first nine postnatal days). In addition, histone and DNA modifications are very dynamic during normal development [143]. These developmental changes may lead to alcohol exposure producing differences in adulthood that are not apparent at 
adolescence or vice versa. For example, prior to adulthood, Solute Carrier Family 17 Member 6 (Slc17a6) mRNA expression is highly expressed in both alcohol- and non-alcohol exposed mice. However, in adulthood, when Slc17a6 mRNA expression normally declines, alcohol-exposed mice continue to express Slc17a6 mRNA at high levels. The abnormally high Slc17a6 mRNA expression is associated with lower promoter DNA methylation in alcohol-exposed mice [144].

An additional challenge to understanding the effects of alcohol on epigenetic parameters and neural cell development is the fact that different neural cell types are characterized by different histone modification and DNA methylation levels. As previously mentioned, alcohol alters neural cell development, leading to changes in proportions of neural cell populations. While this review proposes that alcohol alters epigenetic parameters contributing to differences in neural cell fractions, it is also possible that observed changes in epigenetic measures are a reflection of the different numbers of neural cells present in the brain following alcohol exposure.

Differences in DNA methylation and histone acetylation have been reported in various neural cell types. Mature astrocytes have lower global levels of histone acetylation relative to neurons [76]. In addition, neurons have lower global DNA methylation levels compared with non-neuronal cells [145]. Even among neuronal subtypes, there are differences in DNA methylation characteristics. For example, DNA methylation levels of Vasoactive intestinal polypeptide-expressing (VIP) GABA interneurons are more similar to glia than excitatory or parvalbumin interneurons. This same correlation between glia and VIP neurons was reported in ATAC-seq experiments, in which nucleosome free regions are characterized [146]. It was also reported that $\mathrm{CpH}$ methylation is significantly more abundant in neuronal vs. non-neuronal cells [147], and $\mathrm{CpH}$ methylation is most abundant in parvalbumin positive GABA interneurons [146]. Therefore, until studies emerge in which chromatin changes are measured specifically by cell type, it is difficult to ascertain whether reported alcohol-induced changes in epigenetic parameters are correlative or causative in relation to differences in neural cell populations.

\section{FASD and DNA Methylation}

The lifelong central nervous system phenotypic and gene expression changes caused by prenatal alcohol exposure's effects on chromatin structure are often difficult to discern. This is because there are numerous genes impacted by alcohol in the brain and behavioral phenotypes are often subtle. Examples of more obvious phenotypes directly connecting alcohol-induced DNA methylation and gene expression changes do exist [1]. For example, prenatal alcohol exposure increases Agouti viable yellow $\left(A^{v y}\right)$ intercisternal A-particle (IAP) DNA methylation, producing an increase in the number of offspring with a pseudoagouti coat color and reduced body weight [148]. Similarly, a single alcohol treatment on E9 reduced methylation of the maternally imprinted Insulin Like Growth Factor 2 (Igf2) gene in whole embryos resulting in higher prenatal mortality, lower prenatal growth, and digit and vertebral malformations [149]. The manner and degree to which DNA methylation affects gene expression and phenotype is often not as straightforward as it is for $A^{v y}$ or imprinted genes, especially in the central nervous system. However, from these studies it is apparent that there are instances in which prenatal alcohol's effects on DNA methylation can produce lifelong phenotypic changes.

Altered DNA methylation levels in FASD are likely, at least partially, a consequence of changes in one-carbon metabolism and its involvement with S-adenosylmethionine (SAM) production [150]. SAM serves as a co-substrate for DNA and histone methylation, among many other enzymatic processes [150]. SAM is synthesized, in part, from precursors including folic acid and choline, where homocysteine is a product and precursor of SAM metabolism [151]. Alcohol inhibits folic acid absorption and reduces the ability of methionine synthase to convert homocysteine to methionine, which is often subsequently converted to SAM [152-155]. The fact that maternal dietary folate and choline supplementation have been shown to attenuate the effects of prenatal alcohol exposure supports the notion that a reduced supply of methyl donors is associated with FASD $[156,157]$. 
In cell culture experiments, alcohol has profound effects on DNA methylation. Primary astrocyte cultures treated for $24 \mathrm{~h}$ with alcohol show reduced DNMT expression and activity [158]. Similarly, $48 \mathrm{~h}$ of alcohol treatment of embryonic fibroblasts decreased DNA methylation levels, DNMT expression, and DNMT activity [159]. By contrast, a 48-h treatment of NSC increased DNMT activity and expression [97], but did not affect $5 \mathrm{mC}$ or $5 \mathrm{hmC}$ levels [134]. Longer-term treatment (eight days) increased global levels of $5 \mathrm{mC}$ without affecting $5 \mathrm{hmC}$ levels, and alcohol withdrawal decreased $5 \mathrm{hmC}$ in these cells [134].

The impact of DNA methylation changes on gene expression is partly dependent upon methyl-CpG binding proteins, such as $\mathrm{MeCP} 2$. In embryonic fibroblasts and primary neuronal cultures, alcohol decreased MeCP2 protein expression $[159,160]$. These results contrasted with studies using NSCs in which short-term (48 h) or long-term (eight days) treatment with alcohol increased MeCP2 mRNA and protein expression, while alcohol withdrawal reduced MeCP2 levels [134]. In this study, none of the treatment conditions affected the ultimate numbers of neural cell types [134]. However, all three conditions increased neurite outgrowth [134].

In animal experiments, a growing body of literature suggests that prenatal alcohol exposure decreases DNA methylation when measured during early life (prenatally or neonatally), but increases methylation when measured during adolescence or adulthood, whether measured in the whole embryo, the hippocampus, or the neocortex [161-163]. Alcohol treatment also reduces prenatal and neonatal DNMT expression and activity [158,162]. Similarly, in mice in which alcohol exposure starts from E5 or E6 and continues to E15-16, there are lower hippocampal, striatal, and cortical MeCP2 levels at E17 and at five weeks $[129,164]$. In contrast, prenatal or neonatal alcohol exposure results in an increase in global DNA methylation, DNMT activity, and DNMT expression in the hippocampus, neocortex, and hypothalamus of adolescent or adult rodents [165-170]. Prenatal and postnatal alcohol exposure leads to increased hippocampal, neocortical, and hypothalamic MeCP2 levels at P8 and adulthood [168,170-172] (Table 1).

Interestingly, there are reports that central nervous system genes are particularly sensitive to the effects of prenatal alcohol on DNA methylation. In genome-wide studies of children with prenatal alcohol exposure, DNA methylation changes are especially abundant at neurodevelopmental genes in buccal epithelial cells and blood $[173,174]$. Alcohol treatment preferentially alters DNA methylation levels at genes related to neuronal function in NSCs [175]. Similarly, prenatal alcohol treatment of mice alters DNA methylation in the brain at genes participating in neurological, behavioral, and psychological disorder networks [176]. 
Table 1. Fetal alcohol induced changes in DNA methylation.

\begin{tabular}{|c|c|c|c|c|c|c|c|}
\hline \multicolumn{8}{|c|}{ 5-methylcytosine (5mC) } \\
\hline Global or Gene Specific & Increase or Decrease & Time Alcohol Administered & Time Studied & Brain Region/Cell Culture & Species & Sex & Reference \\
\hline \multirow{11}{*}{ Global } & $\downarrow$ & & $48 \mathrm{~h}$ & embryonic fibroblasts & mice & M & [159] \\
\hline & $\downarrow$ & E8.25 & E10 & Neural tube & mice & $\mathrm{U}$ & [175] \\
\hline & $\downarrow$ & E9-11 & E11 & whole embryo & mice & B & [161] \\
\hline & NC & E5-16 & E17 & ammonic neuroepithelium & mice & B & [164] \\
\hline & $\uparrow$ & E5-16 & E17 & intermediate zone & mice & B & [164] \\
\hline & $\uparrow$ & E5-16 & E17 & hippocampus CA1 & mice & B & [164] \\
\hline & $\downarrow$ & P7 & P8 & hippocampus & mice & B & [162] \\
\hline & $\downarrow$ & P7 & P8 & neocortex & mice & B & [162] \\
\hline & $\uparrow$ & P2-10 & P21 & Prefrontal cortex & rats & B & [165] \\
\hline & $\uparrow$ & P2-10 & P21 & hippocampus & rats & B & [165] \\
\hline & $\mathrm{NC}$ & E7-21 & P60-80 & hypothalamus & rats & $\mathrm{B}$ & [169] \\
\hline \multirow{4}{*}{ Genome-wide } & mostly $\downarrow$ & & $48 \mathrm{~h}$ & NSC & & B & [163] \\
\hline & $\uparrow \downarrow$ & $\mathrm{E} 8-10^{*}$ & E10 & whole embryo & mice & B & [177] \\
\hline & mostly $\uparrow$ & P4 \& P7 & P70 & Hippocampus & mice & $\mathrm{M}$ & [166] \\
\hline & $\uparrow \downarrow$ & & 5-18 yo & Buccal Epithelial Cells & human & B & [173] \\
\hline Cell cycle genes & $\uparrow$ & & $48 \mathrm{~h}$ & NSC & & $\mathrm{F}$ & [97] \\
\hline \multirow{2}{*}{ MeCP2 promoter } & $\uparrow$ & D0-2 & D2 & NSC & mice & B & [134] \\
\hline & $\downarrow$ & D0-8 & D8 & NSC & mice & B & [134] \\
\hline Igf2 & $\downarrow$ & E9 & E9 & whole embryo & mice & $\mathrm{B}$ & [149] \\
\hline Gfap promoter & $\uparrow$ & E1-21 & E21 & whole brain & rats & B & [178] \\
\hline Plat promoter & $\downarrow$ & & $24 \mathrm{~h}$ & primary cortical astrocytes & rats & B & [158] \\
\hline $\begin{array}{c}\text { Imprinted genes (H19 } \\
\text { and IG-DMR) }\end{array}$ & $\downarrow$ & correlated with alcohol drinking & & sperm & human & M & [179] \\
\hline
\end{tabular}


Table 1. Cont.

\begin{tabular}{|c|c|c|c|c|c|c|c|}
\hline \multicolumn{8}{|c|}{ 5-methylcytosine (5mC) } \\
\hline Global or Gene Specific & Increase or Decrease & Time Alcohol Administered & Time Studied & Brain Region/Cell Culture & Species & Sex & Reference \\
\hline KCNQ1OT1 & $\downarrow$ & & $1-26$ yo & blood & human & B & [180] \\
\hline PEG3 promoter & $\downarrow$ & & $1-26$ yo & blood & human & B & [180] \\
\hline Slc6a4 promoter & $\uparrow$ & E1-21 & P55 & hypothalamus & rats & $\mathrm{F}$ & [181] \\
\hline Pomc promoter & $\uparrow$ & E7-21 & P60-80 & hypothalamus & rats & $\mathrm{B}$ & [169] \\
\hline Gm9268 promoter & $\uparrow$ & E0.5-8.5 & P28 & hippocampus & mice & $\mathrm{M}$ & [182] \\
\hline Vpreb2 promoter & $\uparrow$ & E0.5-8.5 & P28 & hippocampus & mice & $\mathrm{M}$ & [182] \\
\hline Olfr601 promoter & $\downarrow$ & E0.5-8.5 & P28 & hippocampus & mice & $\mathrm{M}$ & [182] \\
\hline Slc17a6 promoter & $\downarrow$ & E0.5-8.5 & P120 & hippocampus & mice & M & [144] \\
\hline \multicolumn{8}{|c|}{ 5-hydroxymethylcytosine (5hmC) } \\
\hline Global or Gene Specific & Increase or Decrease & Time Alcohol Administered & Time Studied & Brain Region/Cell Culture & Species & Sex & Reference \\
\hline \multirow{2}{*}{ Global } & $\downarrow$ & E5-16 & E17 & ammonic neuroepithelium & mice & B & [164] \\
\hline & $\downarrow$ & E5-16 & E17 & intermediate zone & mice & B & [164] \\
\hline \multicolumn{8}{|c|}{ DNMT Expression/Activity } \\
\hline $\begin{array}{l}\text { DNMT Isoform mRNA, } \\
\text { Protein, Activity }\end{array}$ & Increase or Decrease & Time Alcohol Administered & Time Studied & Brain Region/Cell Culture & Species & Sex & Reference \\
\hline \multirow{8}{*}{ Dnmt1 mRNA } & $\downarrow$ & & $48 \mathrm{~h}$ & embryonic fibroblasts & mice & M & [159] \\
\hline & $\uparrow$ & & $5 \mathrm{D}$ & neurospheres & mice & B & [183] \\
\hline & $\uparrow$ & D1-3 & D7 & neurospheres & mice & B & [142] \\
\hline & $\mathrm{NC}$ & & $24 \mathrm{~h}$ & primary cortical astrocytes & rats & B & [158] \\
\hline & $\downarrow$ & P90-155 & P155 & sperm & rats & M & [184] \\
\hline & $\downarrow$ & P7 & P8 & hippocampus & mice & B & [162] \\
\hline & $\uparrow$ & P7 & P8 & neocortex & mice & B & [162] \\
\hline & $\uparrow$ & E7-21 & P60-65 & hypothalamus & rats & M & [168] \\
\hline
\end{tabular}


Table 1. Cont

\begin{tabular}{|c|c|c|c|c|c|c|c|}
\hline \multicolumn{8}{|c|}{ DNMT Expression/Activity } \\
\hline $\begin{array}{l}\text { DNMT Isoform mRNA, } \\
\text { Protein, Activity }\end{array}$ & Increase or Decrease & Time Alcohol Administered & Time Studied & Brain Region/Cell Culture & Species & Sex & Reference \\
\hline \multirow{8}{*}{ DNMT1 protein } & $\downarrow$ & & $48 \mathrm{~h}$ & embryonic fibroblasts & mice & $\mathrm{M}$ & [159] \\
\hline & $\uparrow$ & & $48 \mathrm{~h}$ & NSC & & $\mathrm{F}$ & [97] \\
\hline & NC & & $24 \mathrm{~h}$ & primary cortical astrocytes & rats & B & [158] \\
\hline & NC & E6-15 & P35 & striatum & mice & $\mathrm{U}$ & [129] \\
\hline & $\downarrow$ & P7 & P8 & hippocampus & mice & B & [162] \\
\hline & $\mathrm{NC}$ & E6-15 & P35 & cortex & mice & $\mathrm{U}$ & [129] \\
\hline & $\downarrow$ & P7 & P8 & neocortex & mice & B & [162] \\
\hline & $\uparrow$ & E7-21 & P60-65 & hypothalamus & rats & $\mathrm{M}$ & {$[168]$} \\
\hline \multirow{6}{*}{ Dnmt3a mRNA } & $\uparrow$ & & $48 \mathrm{~h}$ & embryonic fibroblasts & mice & $\mathrm{M}$ & [159] \\
\hline & $\mathrm{NC}$ & & $24 \mathrm{~h}$ & primary cortical astrocytes & rats & B & [158] \\
\hline & $\downarrow$ & P7 (high dose) & P8 & hippocampus & mice & $\mathrm{B}$ & {$[162]$} \\
\hline & $\uparrow$ & P7 (low dose) & P8 & hippocampus & mice & B & [170] \\
\hline & $\downarrow$ & P7 (high dose) & P8 & neocortex & mice & B & [162] \\
\hline & $\uparrow$ & P7 (low dose) & P8 & neocortex & mice & B & [170] \\
\hline \multirow{7}{*}{ DNMT3A protein } & $\downarrow$ & & $48 \mathrm{~h}$ & embryonic fibroblasts & mice & $\mathrm{M}$ & [159] \\
\hline & $\downarrow$ & & $24 \mathrm{~h}$ & primary cortical astrocytes & rats & B & {$[158]$} \\
\hline & $\downarrow$ & P7 (high dose) & P8 & hippocampus & mice & B & [162] \\
\hline & $\uparrow$ & P7 (low dose) & P8 & hippocampus & mice & B & {$[170]$} \\
\hline & $\downarrow$ & P7 (high dose) & P8 & neocortex & mice & B & [162] \\
\hline & $\uparrow$ & P7 (low dose) & P8 & neocortex & mice & B & [170] \\
\hline & $\uparrow$ & E7-21 & P60-65 & hypothalamus & rats & $\mathrm{M}$ & {$[168]$} \\
\hline
\end{tabular}


Table 1. Cont

\begin{tabular}{|c|c|c|c|c|c|c|c|}
\hline \multicolumn{8}{|c|}{ DNMT Expression/Activity } \\
\hline $\begin{array}{l}\text { DNMT Isoform mRNA, } \\
\text { Protein, Activity }\end{array}$ & Increase or Decrease & Time Alcohol Administered & Time Studied & Brain Region/Cell Culture & Species & Sex & Reference \\
\hline Dnmt3b mRNA & $\uparrow$ & & $48 \mathrm{~h}$ & embryonic fibroblasts & mice & M & [159] \\
\hline DNMT3B protein & $\downarrow$ & & $48 \mathrm{~h}$ & embryonic fibroblasts & mice & $\mathrm{M}$ & [159] \\
\hline \multirow{4}{*}{ DNMT activity } & $\uparrow$ & & $48 \mathrm{~h}$ & NSC & & $\mathrm{F}$ & [97] \\
\hline & $\downarrow$ & & 24 or $48 \mathrm{~h}$ & primary cortical astrocytes & rats & B & {$[158]$} \\
\hline & $\downarrow$ & E9-11 & E11 & whole embryo & mice & B & [161] \\
\hline & $\uparrow$ & E1-P10 & $\mathrm{P} 21$ & hippocampus & rats & B & [167] \\
\hline \multicolumn{8}{|c|}{ MBD Expression } \\
\hline $\begin{array}{l}\text { MBD Isoform } \\
\text { mRNA/Protein }\end{array}$ & Increase or Decrease & Time Alcohol Administered & Time Studied & Brain Region/Cell Culture & Species & Sex & Reference \\
\hline \multirow{9}{*}{ MeCP2 mRNA } & $\uparrow$ & & $48 \mathrm{~h}$ & embryonic fibroblasts & mice & M & [159] \\
\hline & $\uparrow$ & D0-2 & D2 & NSC & mice & B & [134] \\
\hline & $\uparrow$ & D0-8 & D8 & NSC & mice & B & [134] \\
\hline & $\downarrow$ & D0-2 & D8 & NSC & mice & B & [134] \\
\hline & $\downarrow$ & D3-13 & D13 & primary cortical neurons & mice & B & [160] \\
\hline & $\downarrow$ & D3-8 & D13 & primary cortical neurons & mice & B & {$[160]$} \\
\hline & $\uparrow$ & E7-21 & P60-65 & hypothalamus & rats & $\mathrm{M}$ & [168] \\
\hline & $\mathrm{NC}$ & P7 (low dose) & P8 & hippocampus & mice & B & [170] \\
\hline & $\mathrm{NC}$ & P7 (low dose) & P8 & neocortex & mice & B & [170] \\
\hline
\end{tabular}


Table 1. Cont.

\begin{tabular}{|c|c|c|c|c|c|c|c|}
\hline \multicolumn{8}{|c|}{ MBD Expression } \\
\hline $\begin{array}{l}\text { MBD Isoform } \\
\text { mRNA/Protein }\end{array}$ & Increase or Decrease & Time Alcohol Administered & Time Studied & Brain Region/Cell Culture & Species & Sex & Reference \\
\hline \multirow{13}{*}{$\mathrm{MeCP} 2$ protein } & $\downarrow$ & & $48 \mathrm{~h}$ & embryonic fibroblasts & mice & $\mathrm{M}$ & [159] \\
\hline & $\uparrow$ & D0-2 & D2 & NSC & mice & B & [134] \\
\hline & $\uparrow$ & D0-8 & D8 & NSC & mice & B & [134] \\
\hline & $\downarrow$ & D0-2 & D8 & NSC & mice & B & [134] \\
\hline & $\downarrow$ & D3-13 & D13 & primary cortical neurons & mice & B & [160] \\
\hline & $\downarrow$ & D3-8 & D13 & primary cortical neurons & mice & B & [160] \\
\hline & $\downarrow$ & E6-15 & P35 & striatum & mice & $\mathrm{U}$ & [129] \\
\hline & $\downarrow$ & E5-16 & E17 & hippocampus & mice & B & [164] \\
\hline & $\uparrow$ & P7 (low dose) & P8 & hippocampus & mice & $\mathrm{B}$ & [170] \\
\hline & $\uparrow$ & E8-21 & Adult & hippocampus & rats & $\mathrm{M}$ & {$[171]$} \\
\hline & $\downarrow$ & E6-15 & P35 & cortex & mice & $\mathrm{U}$ & [129] \\
\hline & $\uparrow$ & P7 (low dose) & P8 & neocortex & mice & $\mathrm{B}$ & [170] \\
\hline & $\uparrow$ & E7-21 & P60-65 & hypothalamus & rats & M & [168] \\
\hline Mbd2 mRNA & $\downarrow$ & & $48 \mathrm{~h}$ & embryonic fibroblasts & mice & $\mathrm{M}$ & [159] \\
\hline MBD2 protein & $\downarrow$ & & $48 \mathrm{~h}$ & embryonic fibroblasts & mice & M & [159] \\
\hline Mbd3 mRNA & $\downarrow$ & & $48 \mathrm{~h}$ & embryonic fibroblasts & mice & M & [159] \\
\hline MBD3 protein & $\downarrow$ & & $48 \mathrm{~h}$ & embryonic fibroblasts & mice & $\mathrm{M}$ & [159] \\
\hline
\end{tabular}

Abbreviations: 5mC, 5-methylcytosine; 5hmC, 5-hydroxymethylcytosine; B, Both sexes; CA1, Cornu Ammonis-1; D, Number of days cultured; DNMT1, DNA methyltransferase-1; DNMT3A, DNA methyltransferase-3A; DNMT3B, DNA methyltransferase-3B; E, embryonic day; F, Female; Gfap, Glial fibrillary acidic protein; h, hours; IG-DMR; intergenic-differentially methylated region; Igf2, Insulin Like Growth Factor 2; KCNQ1OT1, KCNQ1 opposite strand/antisense transcript 1; M, Male; MBD, Methyl-CpG binding domain; MeCP2, methyl CpG binding protein 2; NC, No change; NSC, neural stem cells; Olfr601, olfactory receptor 601; P, postnatal day; PEG3, Paternally Expressed 3; Plat, Plasminogen Activator, Tissue Type; Pomc, Pro-opiomelanocortin; Slc17a6, Solute Carrier Family 17 Member 6; Slc6a4, serotonin transporter; U, Unclear; Vpreb2, pre-B lymphocyte gene 2; yo, years old; * Embryo treated ex vivo. 
Table 2. Fetal alcohol induced changes in histone modifications.

\begin{tabular}{|c|c|c|c|c|c|c|c|}
\hline \multicolumn{8}{|c|}{ Histone Acetylation } \\
\hline Global or Gene Specific & Increase or Decrease & Time Alcohol Administered & Time Studied & Brain Region/Cell Culture & Species & Sex & Reference \\
\hline \multirow{3}{*}{ Global } & $\downarrow$ & E7-21 & P60-80 & hypothalamus & rats & $\mathrm{M}$ & [168] \\
\hline & $\downarrow$ & P2-10 & $\mathrm{P} 2-10$ & cerebellum & rats & $\mathrm{B}$ & [185] \\
\hline & $\mathrm{NC}$ & $\mathrm{P} 2-12$ & P12 & cerebellum & rats & B & [185] \\
\hline \multirow{4}{*}{22 Growth factor genes } & $\uparrow$ & D1-3 (low dose) & D3 & NSC & mice & B & [142] \\
\hline & $\downarrow$ & D1-3 (high dose) & D3 & NSC & mice & B & [142] \\
\hline & $\uparrow$ & D1-3 (low dose) & D7 & NSC & mice & B & [142] \\
\hline & $\downarrow$ & D1-3 (high dose) & D7 & NSC & mice & B & [142] \\
\hline Ehmt2 promoter & $\uparrow$ & P7 (low dose) & P8 & neocortex & mice & B & [170] \\
\hline Cnr1 promoter & $\uparrow$ & P7 & P8 & neocortex, hippocamus & mice & B & [177] \\
\hline Dlx2 Promoter & $\uparrow$ & E7 & E17 & neocortex & mice & B & [142] \\
\hline \multicolumn{8}{|c|}{ HAT/HDAC Expression } \\
\hline $\begin{array}{l}\text { HAT/HDAC isoform } \\
\text { mRNA/protein }\end{array}$ & Increase or Decrease & Time Alcohol Administered & Time Studied & Brain Region/Cell Culture & Species & Sex & Reference \\
\hline Crebbp mRNA & $\downarrow$ & E7-21 & P60-80 & hypothalamus & rats & B & [169] \\
\hline CREBBP protein & $\downarrow$ & $\mathrm{P} 2-10$ & P2-10 & cerebellum & rats & B & [185] \\
\hline CREBBP protein & NC & P2-12 & P12 & cerebellum & rats & B & [185] \\
\hline Hdac1 mRNA & $\downarrow$ & P7 & P7 & whole brain & mice & $\mathrm{M}$ & [186] \\
\hline Hdac2 mRNA & $\uparrow$ & E7-21 & P60-80 & hypothalamus & rats & B & [169] \\
\hline
\end{tabular}


Table 2. Cont.

\begin{tabular}{|c|c|c|c|c|c|c|c|}
\hline \multicolumn{8}{|c|}{ H3K4 Methylation } \\
\hline Global or Gene Specific & Increase or Decrease & Time Alcohol Administered & Time Studied & Brain Region/Cell Culture & Species & Sex & Reference \\
\hline Global & $\downarrow$ & E7-21 & P60-65 & hypothalamus & rats & M & [168] \\
\hline \multirow{4}{*}{22 Growth factor genes } & $\uparrow$ & D1-3 (low dose) & D3 & NSC & mice & $\mathrm{B}$ & [142] \\
\hline & $\downarrow$ & D1-3 (high dose) & D3 & NSC & mice & B & [142] \\
\hline & $\uparrow \downarrow$ & D1-3 (low dose) & D7 & NSC & mice & B & [142] \\
\hline & $\uparrow \downarrow$ & D1-3 (high dose) & D7 & NSC & mice & B & [142] \\
\hline Genome-wide & $\uparrow \downarrow$ & P4 \& P7 & P70 & Hippocampus & mice & M & [166] \\
\hline Slc17a6 promoter & $\uparrow$ & E0.5-8.5 & P120 & hippocampus & mice & M & [144] \\
\hline Sox2 Promoter & $\downarrow$ & D1-5 & D5 & neurospheres & mice & B & [183] \\
\hline Dlx2 Promoter & $\downarrow$ & D1-5 & D5 & neurospheres & mice & B & [183] \\
\hline Pax6 Promoter & $\downarrow$ & D1-5 & D5 & neurospheres & mice & B & [183] \\
\hline \multicolumn{8}{|c|}{ H3K4 Methyltransferase/Demethylase Expression } \\
\hline $\begin{array}{l}\text { HMT/Demethylase } \\
\text { isoform mRNA/protein }\end{array}$ & Increase or Decrease & Time Alcohol Administered & Time Studied & Brain Region/Cell Culture & Species & Sex & Reference \\
\hline Ash211 mRNA & $\downarrow$ & D1-5 & D5 & neurospheres & mice & B & [183] \\
\hline Setd7 mRNA & $\downarrow$ & E7-21 & P60-80 & hypothalamus & rats & $\mathrm{M}$ & [168] \\
\hline Kdm1b mRNA & $\downarrow$ & D1-5 & D5 & neurospheres & mice & B & [183] \\
\hline
\end{tabular}


Table 2. Cont.

\begin{tabular}{|c|c|c|c|c|c|c|c|}
\hline \multicolumn{8}{|c|}{ H3K9 Methylation } \\
\hline Global or Gene Specific & Increase or Decrease & Time Alcohol Administered & Time Studied & Brain Region/Cell Culture & Species & Sex & Reference \\
\hline Global & $\uparrow$ & E7-21 & P60-65 & hypothalamus & rats & M & [168] \\
\hline \multirow{6}{*}{22 Growth factor genes } & $\uparrow$ & P7 (high dose) & P8 & hippocampus & mice & $\mathrm{B}$ & [187] \\
\hline & $\uparrow$ & P7 (high dose) & P8 & neocortex & mice & B & [187] \\
\hline & $\downarrow$ & D1-3 (low dose) & D3 & NSC & mice & B & [142] \\
\hline & $\downarrow$ & D1-3 (high dose) & D3 & NSC & mice & $\mathrm{B}$ & [142] \\
\hline & $\uparrow$ & D1-3 (low dose) & D7 & NSC & mice & $\mathrm{B}$ & [142] \\
\hline & $\uparrow$ & D1-3 (high dose) & D7 & NSC & mice & B & [142] \\
\hline Cnr1 promoter & $\downarrow$ & P7 & P8 & neocortex, hippocampus & mice & B & [188] \\
\hline D1x2 Promoter & $\uparrow$ & E7 & E17 & neocortex & mice & B & [142] \\
\hline Dlx3 Promoter & $\uparrow$ & E7 & E17 & neocortex & mice & $\mathrm{B}$ & [142] \\
\hline
\end{tabular}

Abbreviations: Ascl1, Achaete-Scute Family BHLH Transcription Factor 1; Ash2l, Absent, Small, Or Homeotic-Like; B, Both sexes; Cnr1, Cannabinoid 1 receptor; CREBBP, CREB binding protein; D, Number of days cultured; Dlx1, Distal-Less Homeobox 1; Dlx2, Distal-Less Homeobox 2; Dlx3, Distal-Less Homeobox 3; E, embryonic day; EED, Embryonic Ectoderm Development: EHMT1, Euchromatic Histone-Lysine N-Methyltransferase 1· EHMT2, Euchromatic Histone-Lysine N-Methyltransferase 2. EZH2, Enhancer of Zeste 2. F, Female; H3K4, H3 lysine 4; H3K9, H3 lysine 9; H3K27, H3 lysine 27; HATs, Histone acetyltransferases; HDACs, Histone deacetylases; HMT, histone methyltransferase; Kdm1b, Lysine Demethylase 1b; M, Male; NC, No change; NSC, neural stem cells; P, postnatal day; Pax6, Paired Box 6; PRC2, Polycomb Repressive Complex-2; Slc17a6, Solute Carrier Family 17 Member 6; Setd7, SET domain containing (lysine methyltransferase) 7; SETDB1, SET Domain Bifurcated 1; Sox2, (sex determining region Y)-box 2. 
Studies examining the methylation status at FASD candidate genes have also been undertaken. Increased DNA methylation and MeCP2 binding at the Pro-opiomelanocortin (Pomc) and the serotonin transporter (Slc6a4) genes in the hypothalamus $[168,169,172,181]$ and the Gfap promoter in whole brain samples have been reported [178]. Decreased DNA methylation also occurs at the Slc17a6 gene promoter in the hippocampus and the Plasminogen Activator, Tissue Type (Plat) gene in cultured astrocytes [144,158]. Notably, a change in DNA methylation does not always correspond to changes in gene expression in predictable ways. For example, during the third trimester equivalent in rodents, alcohol exposure is associated with DNA methylation and corresponding mRNA changes in only eight genes. In contrast to what might be anticipated, increased DNA methylation is associated with increased expression of five of these eight genes [166].

Taken together, it appears that the immediate effects of prenatal alcohol exposure are to decrease global DNA methylation and MeCP2 levels [129,159-162,164,189,190], while the longer lasting effects, observed during adolescence or adulthood, are an increase in DNA methylation and MeCP2 levels [165,166,168,171,172]. Based on the neurodevelopmental literature, a global reduction in DNA methylation and MeCP2 levels might be expected to promote astrocyte differentiation, and possibly delay or decrease neurogenesis $[72,89]$. In this way, alcohol would be similar to DNMT inhibitor treatment, which is known to induce differentiation along the astrocyte lineage [87]. This was reported in previous studies in which alcohol induces premature transformation of radial glial cells to astrocytes $[139,191-193]$. Further support is indicated by the fact that choline and folate supplementation of maternal or alcohol-exposed pups attenuates the behavioral effects of fetal alcohol exposure and promotes neural stem cell differentiation into neurons both in vitro and in vivo $[87,157,194,195]]$. Moreover, when administered during late gestation (after E18), alcohol induces DNA hypomethylation and lower MeCP2 levels. This may lead to advanced differentiation of astrocytes already committed to that cell fate $[72,87,88]$. These precociously mature astrocytes would likely not be able to support normal neuritogenesis in neighboring neurons [92,196]. In support of this hypothesis, the pretreatment of astrocyte cultures with alcohol reduces neurite outgrowth of subsequently co-cultured neurons [197,198].

\section{FASD and Histone Modifications}

Cell culture experiments reveal that the effects of ethanol on histone modifications are in part dependent upon the dose of ethanol, as well as whether ethanol is present at the time of culture harvesting. Prior ethanol exposure (prolonged withdrawal) in NSC cultures shifts chromatin to a more condensed state compared to when ethanol is still present [142]. Further, lower alcohol doses increase histone acetylation, while higher doses decrease it [142]. In accordance with higher doses and alcohol withdrawal from cell culture inducing more condensed chromatin, high-dose alcohol treatment of neural progenitor cells (NPCs) induces the expression of the H3K9 methytransferase Ehmt1 and decreases expression of the H3K4 methyltransferase complex protein Absent, Small, or Homeotic-Like (Ash2l) transcripts, while withdrawal increases Ehmt2, Setdb1, Eed, and Ezh2 [142,183].

Alcohol exposure during development also alters histone modifications in vivo. The expression of Hdac1 mRNA decreases four hours following alcohol exposure at P7 [199], while Hdac2 expression increases in adulthood in the hypothalamus [169]. Prenatal alcohol exposure reduces histone acetylation and Crebbp mRNA levels in the hypothalamus in adulthood, while neonatal exposure (from P2-12) reduces histone acetylation and CREBBP protein in the cerebellum within $1 \mathrm{~h}$ after the final exposure on P2-10 but no change relative to the control was seen at P12 [169,185].

While the effects of prenatal alcohol on transient histone acetylation marks vary by model and paradigm, prenatal alcohol primarily promotes increases in global levels of restrictive histone methyl marks. Prenatal (E7-21) or early postnatal (P7) alcohol exposures increase global levels of H3K9me2 relative to total $\mathrm{H} 3$ and $\mathrm{H} 3 \mathrm{~K} 27 \mathrm{me} 2$ in the hypothalamus, hippocampus, and neocortex, while reducing H3K4me2/3 [168,169,187,200]. 
Consistent with these findings, fetal or early postnatal alcohol exposure decreases mRNA levels of H3K4 methyltransferase Setd7 and increases mRNA levels of H3K9 methyltransferases Ehmt2 and Setdb1, in the hypothalamus in adulthood, and in the hippocampus and neocortex at P8 [168-170,187].

The functional consequence of an alcohol-induced increase in repressive histone methyl marks is generally, as predicted, decreased gene expression. In a recent meta-analysis of microarray studies, the authors concluded that prenatal alcohol exposure generally leads to reduced levels of gene expression [201]. In a transcriptome-wide study that employed whole mouse brain samples of adult mice exposed during the equivalent of the first, second, and third trimesters of pregnancy, $69 \%$, $77 \%$, and $96 \%$, respectively, of the genes that were differentially expressed were downregulated in the alcohol groups when compared with control groups [186]. On the other hand, a recent study that used DNA isolated by chromatin immunoprecipitation to probe a microarray demonstrated an overall decrease in H3K27me3 levels following third-trimester alcohol exposure at adulthood in the hippocampus (Table 2) [166]. They also reported that the expression of only 60 genes in the adult hippocampus differed from controls following alcohol exposure during the third trimester equivalent. The mRNA levels of two-thirds of these genes were increased [166]. The same study reported that 45 of the alcohol-affected genes exhibited no changes in promoter H3K4me3 or H3K27me3 levels; 11 genes displayed changes in H3K4me3 and four in H3K27me3. Of the 11 genes displaying changes in $\mathrm{H} 3 \mathrm{~K} 4 \mathrm{me}$, five followed the pattern of expression generally associated with this histone modification (i.e., increased H3K4me3 associated with increased expression, or decreased H3K4me3 associated with decreased expression), while the other six did not. All four genes with changes in H3K27me3 displayed decreased H3K27me3 and increased gene expression [166]. This study supports the notion that one or even a few marks in the histone tails do not always determine whether a gene is expressed or not. Gene expression is the result of a more complex interaction between multiple histone tail modifications and cross-talk with intracellular signaling systems [202,203].

Overall, it appears that prenatal alcohol exposure increases histone PTMs associated with condensed chromatin. High doses of ethanol increase H3K9 and H3K27 methyltransferase expression and $\mathrm{H} 3 \mathrm{~K} 9$ and $\mathrm{H} 3 \mathrm{~K} 27$ methylation in cell culture and in animal models. Conversely, ethanol reduces H3K4 methyltransferases and H3K4 methylation levels. As a consequence, overall transcriptional activity is generally reduced in FASD models. We suggest that the functional impact of these changes is to alter neural cell fate. As the genes affected by prenatal alcohol chromatin changes are identified, it may become possible to identify children with FASD earlier in development, and to develop pharmacotherapies to address the associated deficits.

\section{Conclusions}

From the review of the FASD literature, it is apparent that prenatal alcohol exposure alters neural cell differentiation as well as chromatin structure. Future studies associating epigenetic changes induced in well-characterized alcohol models during brain development with alterations in cell genesis and differentiation would constitute an interesting new research direction that may lead to a better understanding of the origins of FASD pathophysiology. These types of studies are particularly important considering that even small variations in the developmental stage at the time of administration, doses of alcohol, or duration of alcohol exposure can lead to different epigenetic responses. This may ultimately lead to a better understanding of the mechanisms behind the cognitive and behavioral manifestations of FASD. In addition, studying these changes in neurons and glial cells separately may provide additional information regarding the impact of alcohol on different brain cells.

There is an emerging literature that suggests that alcohol exposure may induce histone modifications associated with condensed chromatin both globally and specifically at genes involved in neurogenesis in models of second-trimester alcohol exposure, a time when neurogenesis peaks in mammals [142,183]. Restrictive histone marks, such as H3K27me3, suppress neurogenesis to maintain pluripotency early in gestation [65,84-86]. Therefore, an early alcohol exposure-induced increase in H3K27 and decrease in H3K4 methylation might suppress neurogenesis. This anti-neurogenic state is 
further exacerbated by an alcohol-induced reduction in DNA methylation and in the methyl DNA binding protein MeCP2 expression [129,159,161,162,164]. Reduced levels of DNA methylation and MeCP2 would be expected to promote astrogliogenesis at the cost of neurogenesis and to hasten the maturation of astrocytes. In addition to impairing neuronal production, precociously mature astrocytes might not be able to promote normal neuritogenesis. Altered synaptic morphology resulting from altered neuritogenesis could impair neuronal communication manifesting as long-term potentiation and memory deficits.

An obvious challenge to the development of pharmacological treatments for FASD is that, while the insult occurs prenatally, any potential treatment would likely be administered later, after most of the damage has already occurred. Future studies aimed at identifying chromatin abnormalities in peripheral tissues could lead to earlier diagnosis and treatment. Laufer et al. found that DNA methylation of certain CNS genes, such as procadherin, are altered in the buccal swabs of children born with FASD, possibly indicating that some FASD-related DNA methylation perturbations are present in both the CNS and periphery [174]. In addition, by determining which neurodevelopmental processes are perturbed but remain amenable to pharmacological intervention postnatally, it may be possible to develop medications that mitigate the damage caused by prenatal alcohol exposure. In rodents, choline administered during the equivalent of the third trimester of pregnancy in humans or later mitigates some of the cognitive phenotypes associated with FASD, and prevents DNA hypermethylation in the hippocampus and cortex. On the other hand, results from human clinical trials have been somewhat mixed, with some studies showing benefits for affected children and others not finding any beneficial effects $[165,168,204-206]$. Another possible therapeutic approach would be to target cell populations that are still differentiating in humans after birth. Astrocyte differentiation continues during the early postnatal period in humans, and, as examined in this review, is highly reliant upon histone modifications and DNA methylation. Therefore, medications targeting astrocyte development may be especially promising. As the effects of prenatal alcohol on chromatin structure are elucidated, it may become possible to develop drugs that alter histone modifications and/or DNA methylation to restore normal postnatal differentiation and maturation of neural cells, thereby minimizing the neurobehavioral impact of alcohol exposure.

Acknowledgments: This work was supported by the Department of Veterans Affairs: Merit Review Awards BX001819 (Marina Guizzetti) and Career Development Award (CDA-2) IK2BX001650 (David P. Gavin); National Institutes of Health: R01AA021468, R21AA021876, and R01AA022948 (Marina Guizzetti); Center for Alcohol Research in Epigenetics (AA022538) (David P. Gavin and Dennis R. Grayson); and NARSAD Young Investigator Award donation from the family of Joseph M. Evans (David P. Gavin).

Author Contributions: David P. Gavin conceived the concept for this review and wrote the sections on normal neural cell development, epigenetics and FASD. Marina Guizzetti contributed to the sections on astrocyte function and FASD. Dennis R. Grayson contributed to the writing of the epigenetics sections and overall editing. Sajoy P. Varghese designed the figure and assisted with the tables.

Conflicts of Interest: The authors declare no conflict of interest.

\section{References}

1. Lunde, E.R.; Washburn, S.E.; Golding, M.C.; Bake, S.; Miranda, R.C.; Ramadoss, J. Alcohol-induced developmental origins of adult-onset diseases. Alcohol. Clin. Exp. Res. 2016, 40, 1403-1414. [CrossRef] [PubMed]

2. Muller, S.; Chakrapani, B.P.; Schwegler, H.; Hofmann, H.D.; Kirsch, M. Neurogenesis in the dentate gyrus depends on ciliary neurotrophic factor and signal transducer and activator of transcription 3 signaling. Stem Cells 2009, 27, 431-441. [CrossRef] [PubMed]

3. Li, H.; Grumet, M. BMP and LIF signaling coordinately regulate lineage restriction of radial glia in the developing forebrain. Glia 2007, 55, 24-35. [CrossRef] [PubMed]

4. Jiang, X.; Nardelli, J. Cellular and molecular introduction to brain development. Neurobiol. Dis. 2016, 92, 3-17. [CrossRef] [PubMed] 
5. Song, M.R.; Ghosh, A. FGF2-induced chromatin remodeling regulates CNTF-mediated gene expression and astrocyte differentiation. Nat. Neurosci. 2004, 7, 229-235. [CrossRef] [PubMed]

6. Majumder, A.; Dhara, S.K.; Swetenburg, R.; Mithani, M.; Cao, K.; Medrzycki, M.; Fan, Y.; Stice, S.L. Inhibition of DNA methyltransferases and histone deacetylases induces astrocytic differentiation of neural progenitors. Stem Cell Res. 2013, 11, 574-586. [CrossRef] [PubMed]

7. Urayama, S.; Semi, K.; Sanosaka, T.; Hori, Y.; Namihira, M.; Kohyama, J.; Takizawa, T.; Nakashima, K. Chromatin accessibility at a STAT3 target site is altered prior to astrocyte differentiation. Cell Struct. Funct. 2013, 38, 55-66. [CrossRef] [PubMed]

8. Goldberg, A.D.; Allis, C.D.; Bernstein, E. Epigenetics: A landscape takes shape. Cell 2007, 128, 635-638. [CrossRef] [PubMed]

9. Ledford, H. Language: Disputed definitions. Nature 2008, 455, 1023-1028. [PubMed]

10. Laird, P.W. Cancer epigenetics. Hum. Mol. Genet. 2005, 14, R65-R76. [CrossRef] [PubMed]

11. Levenson, J.M.; Sweatt, J.D. Epigenetic mechanisms in memory formation. Nat. Rev. Neurosci. 2005, 6, 108-118. [CrossRef] [PubMed]

12. Barth, T.K.; Imhof, A. Fast signals and slow marks: The dynamics of histone modifications. Trends Biochem. Sci. 2010, 35, 618-626. [CrossRef] [PubMed]

13. Chen, T.; Dent, S.Y. Chromatin modifiers and remodellers: Regulators of cellular differentiation. Nat. Rev. Genet. 2014, 15, 93-106. [CrossRef] [PubMed]

14. Probst, A.V.; Dunleavy, E.; Almouzni, G. Epigenetic inheritance during the cell cycle. Nat. Rev. Mol. Cell. Biol. 2009, 10, 192-206. [CrossRef] [PubMed]

15. Rakyan, V.K.; Chong, S.; Champ, M.E.; Cuthbert, P.C.; Morgan, H.D.; Luu, K.V.; Whitelaw, E. Transgenerational inheritance of epigenetic states at the murine axin(fu) allele occurs after maternal and paternal transmission. Proc. Natl. Acad. Sci. USA 2003, 100, 2538-2543. [CrossRef] [PubMed]

16. Almouzni, G.; Cedar, H. Maintenance of epigenetic information. Cold Spring Harb. Perspect. Biol. 2016. [CrossRef] [PubMed]

17. Commerford, S.L.; Carsten, A.L.; Cronkite, E.P. Histone turnover within nonproliferating cells. Proc. Natl. Acad. Sci. USA 1982, 79, 1163-1165. [CrossRef] [PubMed]

18. Nightingale, K.P.; Gendreizig, S.; White, D.A.; Bradbury, C.; Hollfelder, F.; Turner, B.M. Cross-talk between histone modifications in response to histone deacetylase inhibitors: MLL4 links histone H3 acetylation and histone H3K4 methylation. J. Biol. Chem. 2007, 282, 4408-4416. [CrossRef] [PubMed]

19. Balaraman, S.; Tingling, J.D.; Tsai, P.C.; Miranda, R.C. Dysregulation of microRNA expression and function contributes to the etiology of fetal alcohol spectrum disorders. Alcohol Res. 2013, 35, 18-24. [PubMed]

20. Fierz, B. Dynamic chromatin regulation from a single molecule perspective. ACS Chem. Biol. 2016, 11, 609-620. [CrossRef] [PubMed]

21. Turner, B.M. Cellular memory and the histone code. Cell 2002, 111, 285-291. [CrossRef]

22. Roth, S.Y.; Denu, J.M.; Allis, C.D. Histone acetyltransferases. Annu. Rev. Biochem. 2001, 70, 81-120. [CrossRef] [PubMed]

23. Sharma, R.P.; Gavin, D.P.; Chase, K.A. Heterochromatin as an incubator for pathology and treatment non-response: Implication for neuropsychiatric illness. Pharmacogenom. J. 2012, 12, 361-367. [CrossRef] [PubMed]

24. Trošelj, K.G.; Kujundzic, R.N.; Ugarkovic, D. Polycomb repressive complex's evolutionary conserved function: The role of EZH2 status and cellular background. Clin. Epigenet. 2016, 8, 55. [CrossRef] [PubMed]

25. De Napoles, M.; Mermoud, J.E.; Wakao, R.; Tang, Y.A.; Endoh, M.; Appanah, R.; Nesterova, T.B.; Silva, J.; Otte, A.P.; Vidal, M.; et al. Polycomb group proteins Ring1A/B link ubiquitylation of histone H2A to heritable gene silencing and $X$ inactivation. Dev. Cell 2004, 7, 663-676. [CrossRef] [PubMed]

26. Kriukiene, E.; Liutkeviciute, Z.; Klimasauskas, S. 5-hydroxymethylcytosine-The elusive epigenetic mark in mammalian DNA. Chem. Soc. Rev. 2012, 41, 6916-6930. [CrossRef] [PubMed]

27. Robertson, K.D.; Ait-Si-Ali, S.; Yokochi, T.; Wade, P.A.; Jones, P.L.; Wolffe, A.P. DNMT1 forms a complex with $\mathrm{rb}, \mathrm{E} 2 \mathrm{~F} 1$ and HDAC1 and represses transcription from E2F-responsive promoters. Nat. Genet. 2000, 25, 338-342. [PubMed]

28. Wen, L.; Li, X.; Yan, L.; Tan, Y.; Li, R.; Zhao, Y.; Wang, Y.; Xie, J.; Zhang, Y.; Song, C.; et al. Whole-genome analysis of 5-hydroxymethylcytosine and 5-methylcytosine at base resolution in the human brain. Genome Biol. 2014, 15, R49. [CrossRef] [PubMed] 
29. Wu, H.; Coskun, V.; Tao, J.; Xie, W.; Ge, W.; Yoshikawa, K.; Li, E.; Zhang, Y.; Sun, Y.E. DNMT3A-dependent nonpromoter DNA methylation facilitates transcription of neurogenic genes. Science 2010, 329, 444-448. [CrossRef] [PubMed]

30. Chen, Y.; Damayanti, N.P.; Irudayaraj, J.; Dunn, K.; Zhou, F.C. Diversity of two forms of DNA methylation in the brain. Front. Genet. 2014, 5, 46. [CrossRef] [PubMed]

31. Ito, S.; D'Alessio, A.C.; Taranova, O.V.; Hong, K.; Sowers, L.C.; Zhang, Y. Role of tet proteins in $5 \mathrm{mC}$ to $5 \mathrm{hmC}$ conversion, ES-cell self-renewal and inner cell mass specification. Nature 2010, 466, 1129-1133. [CrossRef] [PubMed]

32. Gavin, D.P.; Chase, K.A.; Sharma, R.P. Active DNA demethylation in post-mitotic neurons: A reason for optimism. Neuropharmacology 2013, 75, 233-245. [CrossRef] [PubMed]

33. Mellen, M.; Ayata, P.; Dewell, S.; Kriaucionis, S.; Heintz, N. MeCP2 binds to 5hmC enriched within active genes and accessible chromatin in the nervous system. Cell 2012, 151, 1417-1430. [CrossRef] [PubMed]

34. Song, C.X.; Szulwach, K.E.; Fu, Y.; Dai, Q.; Yi, C.; Li, X.; Li, Y.; Chen, C.H.; Zhang, W.; Jian, X.; et al. Selective chemical labeling reveals the genome-wide distribution of 5-hydroxymethylcytosine. Nat. Biotechnol. 2011, 29, 68-72. [CrossRef] [PubMed]

35. Ito, S.; Shen, L.; Dai, Q.; Wu, S.C.; Collins, L.B.; Swenberg, J.A.; He, C.; Zhang, Y. Tet proteins can convert 5-methylcytosine to 5-formylcytosine and 5-carboxylcytosine. Science 2011, 333, 1300-1303. [CrossRef] [PubMed]

36. Szulwach, K.E.; Li, X.; Li, Y.; Song, C.X.; Wu, H.; Dai, Q.; Irier, H.; Upadhyay, A.K.; Gearing, M.; Levey, A.I.; et al. 5-hmC-mediated epigenetic dynamics during postnatal neurodevelopment and aging. Nat. Neurosci. 2011, 14, 1607-1616. [CrossRef] [PubMed]

37. Hahn, M.A.; Qiu, R.; Wu, X.; Li, A.X.; Zhang, H.; Wang, J.; Jui, J.; Jin, S.G.; Jiang, Y.; Pfeifer, G.P.; et al. Dynamics of 5-hydroxymethylcytosine and chromatin marks in mammalian neurogenesis. Cell Rep. 2013, 3, 291-300. [CrossRef] [PubMed]

38. Jin, S.G.; Wu, X.; Li, A.X.; Pfeifer, G.P. Genomic mapping of 5-hydroxymethylcytosine in the human brain. Nucleic Acids Res. 2011, 39, 5015-5024. [CrossRef] [PubMed]

39. Lister, R.; Mukamel, E.A.; Nery, J.R.; Urich, M.; Puddifoot, C.A.; Johnson, N.D.; Lucero, J.; Huang, Y.; Dwork, A.J.; Schultz, M.D.; et al. Global epigenomic reconfiguration during mammalian brain development. Science 2013, 341, 1237905. [CrossRef] [PubMed]

40. Khare, T.; Pai, S.; Koncevicius, K.; Pal, M.; Kriukiene, E.; Liutkeviciute, Z.; Irimia, M.; Jia, P.; Ptak, C.; Xia, M.; et al. 5-hmC in the brain is abundant in synaptic genes and shows differences at the exon-intron boundary. Nat. Struct. Mol. Biol. 2012, 19, 1037-1043. [CrossRef] [PubMed]

41. Guo, J.U.; Su, Y.; Shin, J.H.; Shin, J.; Li, H.; Xie, B.; Zhong, C.; Hu, S.; Le, T.; Fan, G.; et al. Distribution, recognition and regulation of non-CpG methylation in the adult mammalian brain. Nat. Neurosci. 2014, 17, 215-222. [CrossRef] [PubMed]

42. Chambers, I. The molecular basis of pluripotency in mouse embryonic stem cells. Cloning Stem Cells 2004, 6, 386-391. [CrossRef] [PubMed]

43. Niwa, H. How is pluripotency determined and maintained? Development 2007, 134, 635-646. [CrossRef] [PubMed]

44. Kageyama, R.; Ohtsuka, T.; Hatakeyama, J.; Ohsawa, R. Roles of bHLH genes in neural stem cell differentiation. Exp. Cell Res. 2005, 306, 343-348. [CrossRef] [PubMed]

45. Petell, C.J.; Alabdi, L.; He, M.; San Miguel, P.; Rose, R.; Gowher, H. An epigenetic switch regulates de novo DNA methylation at a subset of pluripotency gene enhancers during embryonic stem cell differentiation. Nucleic Acids Res. 2016, 44, 7605-7617. [CrossRef] [PubMed]

46. Bhanu, N.V.; Sidoli, S.; Garcia, B.A. Histone modification profiling reveals differential signatures associated with human embryonic stem cell self-renewal and differentiation. Proteomics 2016, 16, 448-458. [CrossRef] [PubMed]

47. Wan, M.; Liang, J.; Xiong, Y.; Shi, F.; Zhang, Y.; Lu, W.; He, Q.; Yang, D.; Chen, R.; Liu, D.; et al. The trithorax group protein Ash2l is essential for pluripotency and maintaining open chromatin in embryonic stem cells. J. Biol. Chem. 2013, 288, 5039-5048. [CrossRef] [PubMed]

48. Kimura, H.; Tada, M.; Nakatsuji, N.; Tada, T. Histone code modifications on pluripotential nuclei of reprogrammed somatic cells. Mol. Cell. Biol. 2004, 24, 5710-5720. [CrossRef] [PubMed] 
49. Hattori, N.; Nishino, K.; Ko, Y.G.; Hattori, N.; Ohgane, J.; Tanaka, S.; Shiota, K. Epigenetic control of mouse oct-4 gene expression in embryonic stem cells and trophoblast stem cells. J. Biol. Chem. 2004, 279, 17063-17069. [CrossRef] [PubMed]

50. O'Neill, L.P.; VerMilyea, M.D.; Turner, B.M. Epigenetic characterization of the early embryo with a chromatin immunoprecipitation protocol applicable to small cell populations. Nat. Genet. 2006, 38, 835-841. [CrossRef] [PubMed]

51. Wu, Q.; Bruce, A.W.; Jedrusik, A.; Ellis, P.D.; Andrews, R.M.; Langford, C.F.; Glover, D.M. CARM1 is required in embryonic stem cells to maintain pluripotency and resist differentiation. Stem Cells 2009, 27, 2637-2645. [CrossRef] [PubMed]

52. Boyer, L.A.; Lee, T.I.; Cole, M.F.; Johnstone, S.E.; Levine, S.S.; Zucker, J.P.; Guenther, M.G.; Kumar, R.M.; Murray, H.L.; Jenner, R.G.; et al. Core transcriptional regulatory circuitry in human embryonic stem cells. Cell 2005, 122, 947-956. [CrossRef] [PubMed]

53. Loh, Y.H.; Wu, Q.; Chew, J.L.; Vega, V.B.; Zhang, W.; Chen, X.; Bourque, G.; George, J.; Leong, B.; Liu, J.; et al. The Oct4 and nanog transcription network regulates pluripotency in mouse embryonic stem cells. Nat. Genet. 2006, 38, 431-440. [CrossRef] [PubMed]

54. Andres, M.E.; Burger, C.; Peral-Rubio, M.J.; Battaglioli, E.; Anderson, M.E.; Grimes, J.; Dallman, J.; Ballas, N.; Mandel, G. CoREST: A functional corepressor required for regulation of neural-specific gene expression. Proc. Natl. Acad. Sci. USA 1999, 96, 9873-9878. [CrossRef] [PubMed]

55. Grimes, J.A.; Nielsen, S.J.; Battaglioli, E.; Miska, E.A.; Speh, J.C.; Berry, D.L.; Atouf, F.; Holdener, B.C.; Mandel, G.; Kouzarides, T. The co-repressor mSin3A is a functional component of the REST-CoREST repressor complex. J. Biol. Chem. 2000, 275, 9461-9467. [CrossRef] [PubMed]

56. Hakimi, M.A.; Bochar, D.A.; Chenoweth, J.; Lane, W.S.; Mandel, G.; Shiekhattar, R. A core-BRAF35 complex containing histone deacetylase mediates repression of neuronal-specific genes. Proc. Natl. Acad. Sci. USA 2002, 99, 7420-7425. [CrossRef] [PubMed]

57. Roopra, A.; Qazi, R.; Schoenike, B.; Daley, T.J.; Morrison, J.F. Localized domains of G9a-mediated histone methylation are required for silencing of neuronal genes. Mol. Cell 2004, 14,727-738. [CrossRef] [PubMed]

58. Mulligan, P.; Westbrook, T.F.; Ottinger, M.; Pavlova, N.; Chang, B.; Macia, E.; Shi, Y.J.; Barretina, J.; Liu, J.; Howley, P.M.; et al. CDYL bridges REST and histone methyltransferases for gene repression and suppression of cellular transformation. Mol. Cell 2008, 32, 718-726. [CrossRef] [PubMed]

59. McGann, J.C.; Oyer, J.A.; Garg, S.; Yao, H.; Liu, J.; Feng, X.; Liao, L.; Yates, J.R., 3rd; Mandel, G. Polycomband REST-associated histone deacetylases are independent pathways toward a mature neuronal phenotype. eLife 2014, 3, e04235. [CrossRef] [PubMed]

60. Boyer, L.A.; Plath, K.; Zeitlinger, J.; Brambrink, T.; Medeiros, L.A.; Lee, T.I.; Levine, S.S.; Wernig, M.; Tajonar, A.; Ray, M.K.; et al. Polycomb complexes repress developmental regulators in murine embryonic stem cells. Nature 2006, 441, 349-353. [CrossRef] [PubMed]

61. Lee, T.I.; Jenner, R.G.; Boyer, L.A.; Guenther, M.G.; Levine, S.S.; Kumar, R.M.; Chevalier, B.; Johnstone, S.E.; Cole, M.F.; Isono, K.; et al. Control of developmental regulators by polycomb in human embryonic stem cells. Cell 2006, 125, 301-313. [CrossRef] [PubMed]

62. Endoh, M.; Endo, T.A.; Endoh, T.; Endoh, T.; Fujimura, Y.; Ohara, O.; Toyoda, T.; Otte, A.P.; Okano, M.; Brockdorff, N.; et al. Polycomb group proteins Ring1A/B are functionally linked to the core transcriptional regulatory circuitry to maintain ES cell identity. Development 2008, 135, 1513-1524. [CrossRef] [PubMed]

63. Jepsen, K.; Solum, D.; Zhou, T.; McEvilly, R.J.; Kim, H.J.; Glass, C.K.; Hermanson, O.; Rosenfeld, M.G. SMRT-mediated repression of an H3K27 demethylase in progression from neural stem cell to neuron. Nature 2007, 450, 415-419. [CrossRef] [PubMed]

64. Park, D.H.; Hong, S.J.; Salinas, R.D.; Liu, S.J.; Sun, S.W.; Sgualdino, J.; Testa, G.; Matzuk, M.M.; Iwamori, N.; Lim, D.A. Activation of neuronal gene expression by the JMJD3 demethylase is required for postnatal and adult brain neurogenesis. Cell Rep. 2014, 8, 1290-1299. [CrossRef] [PubMed]

65. Pereira, J.D.; Sansom, S.N.; Smith, J.; Dobenecker, M.W.; Tarakhovsky, A.; Livesey, F.J. Ezh2, the histone methyltransferase of PRC2, regulates the balance between self-renewal and differentiation in the cerebral cortex. Proc. Natl. Acad. Sci. USA 2010, 107, 15957-15962. [CrossRef] [PubMed]

66. Lim, D.A.; Huang, Y.C.; Swigut, T.; Mirick, A.L.; Garcia-Verdugo, J.M.; Wysocka, J.; Ernst, P.; Alvarez-Buylla, A. Chromatin remodelling factor Mll1 is essential for neurogenesis from postnatal neural stem cells. Nature 2009, 458, 529-533. [CrossRef] [PubMed] 
67. Guizzetti, M.; Zhang, X.; Goeke, C.; Gavin, D.P. Glia and neurodevelopment: Focus on fetal alcohol spectrum disorders. Front. Pediatr. 2014, 2, 123. [CrossRef] [PubMed]

68. Molofsky, A.V.; Krencik, R.; Ullian, E.M.; Tsai, H.H.; Deneen, B.; Richardson, W.D.; Barres, B.A.; Rowitch, D.H. Astrocytes and disease: A neurodevelopmental perspective. Genes Dev. 2012, 26, 891-907. [CrossRef] [PubMed]

69. Parpura, V.; Heneka, M.T.; Montana, V.; Oliet, S.H.; Schousboe, A.; Haydon, P.G.; Stout, R.F., Jr; Spray, D.C.; Reichenbach, A.; Pannicke, T.; et al. Glial cells in (patho) physiology. J. Neurochem. 2012, 121, 4-27. [CrossRef] [PubMed]

70. Parpura, V.; Haydon, P.G. Physiological astrocytic calcium levels stimulate glutamate release to modulate adjacent neurons. Proc. Natl. Acad. Sci. USA 2000, 97, 8629-8634. [CrossRef] [PubMed]

71. Takizawa, T.; Nakashima, K.; Namihira, M.; Ochiai, W.; Uemura, A.; Yanagisawa, M.; Fujita, N.; Nakao, M.; Taga, T. DNA methylation is a critical cell-intrinsic determinant of astrocyte differentiation in the fetal brain. Dev. Cell 2001, 1, 749-758. [CrossRef]

72. Fan, G.; Martinowich, K.; Chin, M.H.; He, F.; Fouse, S.D.; Hutnick, L.; Hattori, D.; Ge, W.; Shen, Y.; Wu, H.; et al. DNA methylation controls the timing of astrogliogenesis through regulation of JAK-STAT signaling. Development 2005, 132, 3345-3356. [CrossRef] [PubMed]

73. Sun, Y.; Nadal-Vicens, M.; Misono, S.; Lin, M.Z.; Zubiaga, A.; Hua, X.; Fan, G.; Greenberg, M.E. Neurogenin promotes neurogenesis and inhibits glial differentiation by independent mechanisms. Cell 2001, 104, 365-376. [CrossRef]

74. Lee, H.J.; Dreyfus, C.; DiCicco-Bloom, E. Valproic acid stimulates proliferation of glial precursors during cortical gliogenesis in developing rat. Dev. Neurobiol. 2015, 76, 780-798. [CrossRef] [PubMed]

75. Shaked, M.; Weissmuller, K.; Svoboda, H.; Hortschansky, P.; Nishino, N.; Wolfl, S.; Tucker, K.L. Histone deacetylases control neurogenesis in embryonic brain by inhibition of BMP2/4 signaling. PLoS ONE 2008, 3, e2668. [CrossRef] [PubMed]

76. Hsieh, J.; Nakashima, K.; Kuwabara, T.; Mejia, E.; Gage, F.H. Histone deacetylase inhibition-mediated neuronal differentiation of multipotent adult neural progenitor cells. Proc. Natl. Acad. Sci. USA 2004, 101, 16659-16664. [CrossRef] [PubMed]

77. Laeng, P.; Pitts, R.L.; Lemire, A.L.; Drabik, C.E.; Weiner, A.; Tang, H.; Thyagarajan, R.; Mallon, B.S.; Altar, C.A. The mood stabilizer valproic acid stimulates GABA neurogenesis from rat forebrain stem cells. J. Neurochem. 2004, 91, 238-251. [CrossRef] [PubMed]

78. Greenway, D.J.; Street, M.; Jeffries, A.; Buckley, N.J. RE1 silencing transcription factor maintains a repressive chromatin environment in embryonic hippocampal neural stem cells. Stem Cells 2007, 25, 354-363. [CrossRef] [PubMed]

79. Yasuda, S.; Liang, M.H.; Marinova, Z.; Yahyavi, A.; Chuang, D.M. The mood stabilizers lithium and valproate selectively activate the promoter IV of brain-derived neurotrophic factor in neurons. Mol. Psychiatry 2009, 14, 51-59. [CrossRef] [PubMed]

80. Xu, D.; Qu, C.K. Protein tyrosine phosphatases in the JAK/STAT pathway. Front. Biosci. 2008, 13, 4925-4932. [CrossRef] [PubMed]

81. Kanski, R.; Sneeboer, M.A.; van Bodegraven, E.J.; Sluijs, J.A.; Kropff, W.; Vermunt, M.W.; Creyghton, M.P.; De Filippis, L.; Vescovi, A.; Aronica, E.; et al. Histone acetylation in astrocytes suppresses GFAP and stimulates a reorganization of the intermediate filament network. J. Cell Sci. 2014, 127, 4368-4380. [CrossRef] [PubMed]

82. Zhang, D.; Yoon, H.G.; Wong, J. JMJD2A is a novel N-CoR-interacting protein and is involved in repression of the human transcription factor achaete scute-like homologue 2 (ASCL2/Hash2). Mol. Cell. Biol. 2005, 25, 6404-6414. [CrossRef] [PubMed]

83. Cascante, A.; Klum, S.; Biswas, M.; Antolin-Fontes, B.; Barnabe-Heider, F.; Hermanson, O. Gene-specific methylation control of $\mathrm{H} 3 \mathrm{~K} 9$ and $\mathrm{H} 3 \mathrm{~K} 36$ on neurotrophic BDNF versus astroglial GFAP genes by KDM4A/C regulates neural stem cell differentiation. J. Mol. Biol. 2014, 426, 3467-3477. [CrossRef] [PubMed]

84. Hirabayashi, Y.; Suzki, N.; Tsuboi, M.; Endo, T.A.; Toyoda, T.; Shinga, J.; Koseki, H.; Vidal, M.; Gotoh, Y. Polycomb limits the neurogenic competence of neural precursor cells to promote astrogenic fate transition. Neuron 2009, 63, 600-613. [CrossRef] [PubMed]

85. Levers, T.E.; Edgar, J.M.; Price, D.J. The fates of cells generated at the end of neurogenesis in developing mouse cortex. J. Neurobiol. 2001, 48, 265-277. [CrossRef] [PubMed] 
86. Sparmann, A.; Xie, Y.; Verhoeven, E.; Vermeulen, M.; Lancini, C.; Gargiulo, G.; Hulsman, D.; Mann, M.; Knoblich, J.A.; van Lohuizen, M. The chromodomain helicase Chd4 is required for polycomb-mediated inhibition of astroglial differentiation. EMBO J. 2013, 32, 1598-1612. [CrossRef] [PubMed]

87. Amarger, V.; Lecouillard, A.; Ancellet, L.; Grit, I.; Castellano, B.; Hulin, P.; Parnet, P. Protein content and methyl donors in maternal diet interact to influence the proliferation rate and cell fate of neural stem cells in rat hippocampus. Nutrients 2014, 6, 4200-4217. [CrossRef] [PubMed]

88. Wu, Z.; Huang, K.; Yu, J.; Le, T.; Namihira, M.; Liu, Y.; Zhang, J.; Xue, Z.; Cheng, L.; Fan, G. Dnmt3a regulates both proliferation and differentiation of mouse neural stem cells. J. Neurosci. Res. 2012, 90, 1883-1891. [CrossRef] [PubMed]

89. Andoh-Noda, T.; Akamatsu, W.; Miyake, K.; Matsumoto, T.; Yamaguchi, R.; Sanosaka, T.; Okada, Y.; Kobayashi, T.; Ohyama, M.; Nakashima, K.; et al. Differentiation of multipotent neural stem cells derived from rett syndrome patients is biased toward the astrocytic lineage. Mol. Brain 2015, 8, 31. [CrossRef] [PubMed]

90. Namihira, M.; Kohyama, J.; Semi, K.; Sanosaka, T.; Deneen, B.; Taga, T.; Nakashima, K. Committed neuronal precursors confer astrocytic potential on residual neural precursor cells. Dev. Cell 2009, 16, 245-255. [CrossRef] [PubMed]

91. Nakashima, K.; Yanagisawa, M.; Arakawa, H.; Kimura, N.; Hisatsune, T.; Kawabata, M.; Miyazono, K.; Taga, T. Synergistic signaling in fetal brain by STAT3-Smad1 complex bridged by p300. Science 1999, 284, 479-482. [CrossRef] [PubMed]

92. Ballas, N.; Lioy, D.T.; Grunseich, C.; Mandel, G. Non-cell autonomous influence of MeCP2-deficient glia on neuronal dendritic morphology. Nat. Neurosci. 2009, 12, 311-317. [CrossRef] [PubMed]

93. Kishi, N.; Macklis, J.D. MeCP2 functions largely cell-autonomously, but also non-cell-autonomously, in neuronal maturation and dendritic arborization of cortical pyramidal neurons. Exp. Neurol. 2010, 222, 51-58. [CrossRef] [PubMed]

94. Lioy, D.T.; Garg, S.K.; Monaghan, C.E.; Raber, J.; Foust, K.D.; Kaspar, B.K.; Hirrlinger, P.G.; Kirchhoff, F.; Bissonnette, J.M.; Ballas, N.; et al. A role for glia in the progression of rett's syndrome. Nature 2011, 475, 497-500. [CrossRef] [PubMed]

95. Pawlak, R.; Skrzypiec, A.; Sulkowski, S.; Buczko, W. Ethanol-induced neurotoxicity is counterbalanced by increased cell proliferation in mouse dentate gyrus. Neurosci. Lett. 2002, 327, 83-86. [CrossRef]

96. Nash, R.J.; Heimburg-Molinaro, J.; Nash, R.J. Heparin binding epidermal growth factor-like growth factor reduces ethanol-induced apoptosis and differentiation in human embryonic stem cells. Growth Factors 2009, 27, 362-369. [CrossRef] [PubMed]

97. Hicks, S.D.; Middleton, F.A.; Miller, M.W. Ethanol-induced methylation of cell cycle genes in neural stem cells. J. Neurochem. 2010, 114, 1767-1780. [CrossRef] [PubMed]

98. Krishnamoorthy, M.; Gerwe, B.A.; Scharer, C.D.; Heimburg-Molinaro, J.; Gregory, F.; Nash, R.J.; Arumugham, J.; Stewart, B.; Stice, S.L.; Nash, R.J. Low ethanol concentration alters CHRNA5 RNA levels during early human development. Reprod. Toxicol. 2010, 30, 489-492. [CrossRef] [PubMed]

99. Krishnamoorthy, M.; Gerwe, B.A.; Scharer, C.D.; Heimburg-Molinaro, J.; Gregory, F.; Nash, R.J.; Arumugham, J.; Usta, S.N.; Eilertson, C.D.; Stice, S.L.; et al. GABRB3 gene expression increases upon ethanol exposure in human embryonic stem cells. J. Recept. Signal. Transduct. Res. 2011, 31, $206-213$. [CrossRef] [PubMed]

100. Kim, K.C.; Go, H.S.; Bak, H.R.; Choi, C.S.; Choi, I.; Kim, P.; Han, S.H.; Han, S.M.; Shin, C.Y.; Ko, K.H. Prenatal exposure of ethanol induces increased glutamatergic neuronal differentiation of neural progenitor cells. J. Biomed. Sci. 2010, 17, 85. [CrossRef] [PubMed]

101. Krishnamoorthy, M.; Gerwe, B.A.; Scharer, C.D.; Sahasranaman, V.; Eilertson, C.D.; Nash, R.J.; Usta, S.N.; Kelly, S.; Rose, M.; Peraza, R.; et al. Ethanol alters proliferation and differentiation of normal and chromosomally abnormal human embryonic stem cell-derived neurospheres. Birth Defects Res. B Dev. Reprod. Toxicol. 2013, 98, 283-295. [CrossRef] [PubMed]

102. Barnes, D.E.; Walker, D.W. Prenatal ethanol exposure permanently reduces the number of pyramidal neurons in rat hippocampus. Brain Res. 1981, 227, 333-340. [CrossRef]

103. Miller, M.W. Generation of neurons in the rat dentate gyrus and hippocampus: Effects of prenatal and postnatal treatment with ethanol. Alcohol. Clin. Exp. Res. 1995, 19, 1500-1509. [CrossRef] [PubMed] 
104. Wigal, T.; Amsel, A. Behavioral and neuroanatomical effects of prenatal, postnatal, or combined exposure to ethanol in weanling rats. Behav. Neurosci. 1990, 104, 116-126. [CrossRef] [PubMed]

105. Bayer, S.A.; Yackel, J.W.; Puri, P.S. Neurons in the rat dentate gyrus granular layer substantially increase during juvenile and adult life. Science 1982, 216, 890-892. [CrossRef] [PubMed]

106. Rami, A.; Patel, A.J.; Rabie, A. Thyroid hormone and development of the rat hippocampus: Morphological alterations in granule and pyramidal cells. Neuroscience 1986, 19, 1217-1226. [CrossRef]

107. Bonthius, D.J.; West, J.R. Alcohol-induced neuronal loss in developing rats: Increased brain damage with binge exposure. Alcohol. Clin. Exp. Res. 1990, 14, 107-118. [CrossRef] [PubMed]

108. Bonthius, D.J.; West, J.R. Permanent neuronal deficits in rats exposed to alcohol during the brain growth spurt. Teratology 1991, 44, 147-163. [CrossRef] [PubMed]

109. Bonthius, D.J.; Woodhouse, J.; Bonthius, N.E.; Taggard, D.A.; Lothman, E.W. Reduced seizure threshold and hippocampal cell loss in rats exposed to alcohol during the brain growth spurt. Alcohol. Clin. Exp. Res. 2001, 25, 70-82. [CrossRef] [PubMed]

110. Greene, P.L.; Diaz-Granados, J.L.; Amsel, A. Blood ethanol concentration from early postnatal exposure: Effects on memory-based learning and hippocampal neuroanatomy in infant and adult rats. Behav. Neurosci. 1992, 106, 51-61. [CrossRef] [PubMed]

111. Tran, T.D.; Kelly, S.J. Critical periods for ethanol-induced cell loss in the hippocampal formation. Neurotoxicol. Teratol. 2003, 25, 519-528. [CrossRef]

112. Borges, S.; Lewis, P.D. A study of alcohol effects on the brain during gestation and lactation. Teratology 1982, 25, 283-289. [CrossRef] [PubMed]

113. Borges, S.; Lewis, P.D. The effect of ethanol on the cellular composition of the cerebellum. Neuropathol. Appl. Neurobiol. 1983, 9, 53-60. [CrossRef] [PubMed]

114. Phillips, S.C.; Cragg, B.G. A change in susceptibility of rat cerebellar purkinje cells to damage by acetaldehyde during fetal, neonatal and adult life. Neuropathol. Appl. Neurobiol. 1982, 8, 455-463. [CrossRef] [PubMed]

115. Volk, B. Cerebellar histogenesis and synaptic maturation following pre- and postnatal alcohol administration: An electron-microscopic investigation of the rat cerebellar cortex. Acta Neuropathol. 1984, 63, 57-65. [CrossRef] [PubMed]

116. Miller, M.W. Effects of alcohol on the generation and migration of cerebral cortical neurons. Science 1986, 233, 1308-1311. [CrossRef] [PubMed]

117. Miller, M.W. Effect of prenatal exposure to alcohol on the distribution and time of origin of corticospinal neurons in the rat. J. Comp. Neurol. 1987, 257, 372-382. [CrossRef] [PubMed]

118. Cragg, B.; Phillips, S. Natural loss of purkinje cells during development and increased loss with alcohol. Brain Res. 1985, 325, 151-160. [CrossRef]

119. Marcussen, B.L.; Goodlett, C.R.; Mahoney, J.C.; West, J.R. Developing rat purkinje cells are more vulnerable to alcohol-induced depletion during differentiation than during neurogenesis. Alcohol 1994, 11, 147-156. [CrossRef]

120. Hamre, K.M.; West, J.R. The effects of the timing of ethanol exposure during the brain growth spurt on the number of cerebellar purkinje and granule cell nuclear profiles. Alcohol. Clin. Exp. Res. 1993, 17, 610-622. [CrossRef] [PubMed]

121. Kotkoskie, L.A.; Norton, S. Cerebral cortical morphology and behavior in rats following acute prenatal ethanol exposure. Alcohol. Clin. Exp. Res. 1989, 13, 776-781. [CrossRef] [PubMed]

122. Pennington, S.N.; Boyd, J.W.; Kalmus, G.W.; Wilson, R.W. The molecular mechanism of fetal alcohol syndrome (FAS). I. ethanol-induced growth suppression. Neurobehav. Toxicol. Teratol. 1983, 5, $259-262$. [PubMed]

123. Ledig, M.; Ciesielski, L.; Simler, S.; Lorentz, J.G.; Mandel, P. Effect of pre- and postnatal alcohol consumption on GABA levels of various brain regions in the rat offspring. Alcohol Alcohol. 1988, 23, 63-67. [PubMed]

124. Miller, M.W. Effect of prenatal exposure to ethanol on glutamate and GABA immunoreactivity in macaque somatosensory and motor cortices: Critical timing of exposure. Neuroscience 2006, 138, 97-107. [CrossRef] [PubMed]

125. Bailey, C.D.; Brien, J.F.; Reynolds, J.N. Chronic prenatal ethanol exposure alters the proportion of GABAergic neurons in layers II/III of the adult guinea pig somatosensory cortex. Neurotoxicol. Teratol. 2004, 26, 59-63. [CrossRef] [PubMed] 
126. Hsiao, S.H.; Parrish, A.R.; Nahm, S.S.; Abbott, L.C.; McCool, B.A.; Frye, G.D. Effects of early postnatal ethanol intubation on GABAergic synaptic proteins. Dev. Brain Res. 2002, 138, 177-185. [CrossRef]

127. Hsiao, S.H.; DuBois, D.W.; Miranda, R.C.; Frye, G.D. Critically timed ethanol exposure reduces GABAAR function on septal neurons developing in vivo but not in vitro. Brain Res. 2004, 1008, 69-80. [CrossRef] [PubMed]

128. DuBois, D.W.; Parrish, A.R.; Trzeciakowski, J.P.; Frye, G.D. Binge ethanol exposure delays development of GABAergic miniature postsynaptic currents in septal neurons. Dev. Brain Res. 2004, 152, 199-212. [CrossRef] [PubMed]

129. Kim, P.; Park, J.H.; Choi, C.S.; Choi, I.; Joo, S.H.; Kim, M.K.; Kim, S.Y.; Kim, K.C.; Park, S.H.; Kwon, K.J.; et al. Effects of ethanol exposure during early pregnancy in hyperactive, inattentive and impulsive behaviors and MeCP2 expression in rodent offspring. Neurochem. Res. 2013, 38, 620-631. [CrossRef] [PubMed]

130. Miller, M.W. Effect of prenatal exposure to ethanol on the development of cerebral cortex: I. Neuronal generation. Alcohol. Clin. Exp. Res. 1988, 12, 440-449. [CrossRef] [PubMed]

131. Miller, M.W. Effects of prenatal exposure to ethanol on callosal projection neurons in rat somatosensory cortex. Brain Res. 1997, 766, 121-128. [CrossRef]

132. Al-Rabiai, S.; Miller, M.W. Effect of prenatal exposure to ethanol on the ultrastructure of layer V of mature rat somatosensory cortex. J. Neurocytol. 1989, 18, 711-729. [CrossRef] [PubMed]

133. Benuskova, L.; Rema, V.; Armstrong-James, M.; Ebner, F.F. Theory for normal and impaired experience-dependent plasticity in neocortex of adult rats. Proc. Natl. Acad. Sci. USA 2001, 98, 2797-2802. [CrossRef] [PubMed]

134. Liyanage, V.R.; Zachariah, R.M.; Davie, J.R.; Rastegar, M. Ethanol deregulates Mecp2/MeCP2 in differentiating neural stem cells via interplay between 5-methylcytosine and 5-hydroxymethylcytosine at the Mecp2 regulatory elements. Exp. Neurol. 2015, 265, 102-117. [CrossRef] [PubMed]

135. Guizzetti, M.; Costa, L.G. Inhibition of muscarinic receptor-stimulated glial cell proliferation by ethanol. J. Neurochem. 1996, 67, 2236-2245. [CrossRef] [PubMed]

136. Guerri, C.; Pascual, M.; Renau-Piqueras, J. Glia and fetal alcohol syndrome. Neurotoxicology 2001, 22, 593-599. [CrossRef]

137. Valles, S.; Sancho-Tello, M.; Minana, R.; Climent, E.; Renau-Piqueras, J.; Guerri, C. Glial fibrillary acidic protein expression in rat brain and in radial glia culture is delayed by prenatal ethanol exposure. J. Neurochem. 1996, 67, 2425-2433. [CrossRef] [PubMed]

138. Fletcher, T.L.; Shain, W. Ethanol-induced changes in astrocyte gene expression during rat central nervous system development. Alcohol. Clin. Exp. Res. 1993, 17, 993-1001. [CrossRef] [PubMed]

139. Goodlett, C.R.; Leo, J.T.; O'Callaghan, J.P.; Mahoney, J.C.; West, J.R. Transient cortical astrogliosis induced by alcohol exposure during the neonatal brain growth spurt in rats. Dev. Brain Res. 1993, 72, 85-97. [CrossRef]

140. Goodlett, C.R.; Peterson, S.D.; Lundahl, K.R.; Pearlman, A.D. Binge-like alcohol exposure of neonatal rats via intragastric intubation induces both purkinje cell loss and cortical astrogliosis. Alcohol. Clin. Exp. Res. 1997, 21, 1010-1017. [CrossRef] [PubMed]

141. Topper, L.A.; Baculis, B.C.; Valenzuela, C.F. Exposure of neonatal rats to alcohol has differential effects on neuroinflammation and neuronal survival in the cerebellum and hippocampus. J. Neuroinflamm. 2015, 12, 160. [CrossRef] [PubMed]

142. Veazey, K.J.; Parnell, S.E.; Miranda, R.C.; Golding, M.C. Dose-dependent alcohol-induced alterations in chromatin structure persist beyond the window of exposure and correlate with fetal alcohol syndrome birth defects. Epigenet. Chromatin 2015, 8, 39. [CrossRef] [PubMed]

143. Numata, S.; Ye, T.; Hyde, T.M.; Guitart-Navarro, X.; Tao, R.; Wininger, M.; Colantuoni, C.; Weinberger, D.R.; Kleinman, J.E.; Lipska, B.K. DNA methylation signatures in development and aging of the human prefrontal cortex. Am. J. Hum. Genet. 2012, 90, 260-272. [CrossRef] [PubMed]

144. Zhang, C.R.; Ho, M.F.; Vega, M.C.; Burne, T.H.; Chong, S. Prenatal ethanol exposure alters adult hippocampal VGLUT2 expression with concomitant changes in promoter DNA methylation, H3K4 trimethylation and miR-467b-5p levels. Epigenet. Chromatin 2015, 8, 40. [CrossRef] [PubMed]

145. Iwamoto, K.; Bundo, M.; Ueda, J.; Oldham, M.C.; Ukai, W.; Hashimoto, E.; Saito, T.; Geschwind, D.H.; Kato, T. Neurons show distinctive DNA methylation profile and higher interindividual variations compared with non-neurons. Genome Res. 2011, 21, 688-696. [CrossRef] [PubMed] 
146. Mo, A.; Mukamel, E.A.; Davis, F.P.; Luo, C.; Henry, G.L.; Picard, S.; Urich, M.A.; Nery, J.R.; Sejnowski, T.J.; Lister, R.; et al. Epigenomic signatures of neuronal diversity in the mammalian brain. Neuron 2015, 86, 1369-1384. [CrossRef] [PubMed]

147. Kozlenkov, A.; Roussos, P.; Timashpolsky, A.; Barbu, M.; Rudchenko, S.; Bibikova, M.; Klotzle, B.; Byne, W.; Lyddon, R.; Di Narzo, A.F.; et al. Differences in DNA methylation between human neuronal and glial cells are concentrated in enhancers and non-CpG sites. Nucleic Acids Res. 2014, 42, 109-127. [CrossRef] [PubMed]

148. Kaminen-Ahola, N.; Ahola, A.; Maga, M.; Mallitt, K.A.; Fahey, P.; Cox, T.C.; Whitelaw, E.; Chong, S. Maternal ethanol consumption alters the epigenotype and the phenotype of offspring in a mouse model. PLoS Genet. 2010, 6, e1000811. [CrossRef] [PubMed]

149. Downing, C.; Johnson, T.E.; Larson, C.; Leakey, T.I.; Siegfried, R.N.; Rafferty, T.M.; Cooney, C.A. Subtle decreases in DNA methylation and gene expression at the mouse Igf2 locus following prenatal alcohol exposure: Effects of a methyl-supplemented diet. Alcohol 2011, 45, 65-71. [CrossRef] [PubMed]

150. Varela-Rey, M.; Woodhoo, A.; Martinez-Chantar, M.L.; Mato, J.M.; Lu, S.C. Alcohol, DNA methylation, and cancer. Alcohol Res. 2013, 35, 25-35. [PubMed]

151. Mandaviya, P.R.; Stolk, L.; Heil, S.G. Homocysteine and DNA methylation: A review of animal and human literature. Mol. Genet. Metab. 2014, 113, 243-252. [CrossRef] [PubMed]

152. Kenyon, S.H.; Nicolaou, A.; Gibbons, W.A. The effect of ethanol and its metabolites upon methionine synthase activity in vitro. Alcohol 1998, 15, 305-309. [CrossRef]

153. Hutson, J.R.; Stade, B.; Lehotay, D.C.; Collier, C.P.; Kapur, B.M. Folic acid transport to the human fetus is decreased in pregnancies with chronic alcohol exposure. PLoS ONE 2012, 7, e38057. [CrossRef] [PubMed]

154. Barak, A.J.; Beckenhauer, H.C.; Tuma, D.J.; Badakhsh, S. Effects of prolonged ethanol feeding on methionine metabolism in rat liver. Biochem. Cell Biol. 1987, 65, 230-233. [CrossRef] [PubMed]

155. Barak, A.J.; Tuma, D.J.; Beckenhauer, H.C. Ethanol, the choline requirement, methylation and liver injury. Life Sci. 1985, 37, 789-791. [CrossRef]

156. Wang, L.L.; Zhang, Z.; Li, Q.; Yang, R.; Pei, X.; Xu, Y.; Wang, J.; Zhou, S.F.; Li, Y. Ethanol exposure induces differential microRNA and target gene expression and teratogenic effects which can be suppressed by folic acid supplementation. Hum. Reprod. 2009, 24, 562-579. [CrossRef] [PubMed]

157. Thomas, J.D.; Idrus, N.M.; Monk, B.R.; Dominguez, H.D. Prenatal choline supplementation mitigates behavioral alterations associated with prenatal alcohol exposure in rats. Birth Defects Res. A Clin. Mol. Teratol. 2010, 88, 827-837. [CrossRef] [PubMed]

158. Zhang, X.; Kusumo, H.; Sakharkar, A.J.; Pandey, S.C.; Guizzetti, M. Regulation of DNA methylation by ethanol induces tissue plasminogen activator expression in astrocytes. J. Neurochem. 2014, 128, 344-349. [CrossRef] [PubMed]

159. Mukhopadhyay, P.; Rezzoug, F.; Kaikaus, J.; Greene, R.M.; Pisano, M.M. Alcohol modulates expression of DNA methyltranferases and methyl CpG-/CpG domain-binding proteins in murine embryonic fibroblasts. Reprod. Toxicol. 2013, 37, 40-48. [CrossRef] [PubMed]

160. Guo, Y.; Chen, Y.; Carreon, S.; Qiang, M. Chronic intermittent ethanol exposure and its removal induce a different miRNA expression pattern in primary cortical neuronal cultures. Alcohol. Clin. Exp. Res. 2012, 36, 1058-1066. [CrossRef] [PubMed]

161. Garro, A.J.; McBeth, D.L.; Lima, V.; Lieber, C.S. Ethanol consumption inhibits fetal DNA methylation in mice: Implications for the fetal alcohol syndrome. Alcohol. Clin. Exp. Res. 1991, 15, 395-398. [CrossRef] [PubMed]

162. Nagre, N.N.; Subbanna, S.; Shivakumar, M.; Psychoyos, D.; Basavarajappa, B.S. CB1-receptor knockout neonatal mice are protected against ethanol-induced impairments of DNMT1, DNMT3A, and DNA methylation. J. Neurochem. 2015, 132, 429-442. [CrossRef] [PubMed]

163. Zhou, F.C.; Chen, Y.; Love, A. Cellular DNA methylation program during neurulation and its alteration by alcohol exposure. Birth Defects Res. A Clin. Mol. Teratol. 2011, 91, 703-715. [CrossRef] [PubMed]

164. Chen, Y.; Ozturk, N.C.; Zhou, F.C. DNA methylation program in developing hippocampus and its alteration by alcohol. PLoS ONE 2013, 8, e60503. [CrossRef] [PubMed]

165. Otero, N.K.; Thomas, J.D.; Saski, C.A.; Xia, X.; Kelly, S.J. Choline supplementation and DNA methylation in the hippocampus and prefrontal cortex of rats exposed to alcohol during development. Alcohol. Clin. Exp. Res. 2012, 36, 1701-1709. [CrossRef] [PubMed] 
166. Chater-Diehl, E.J.; Laufer, B.I.; Castellani, C.A.; Alberry, B.L.; Singh, S.M. Alteration of gene expression, DNA methylation, and histone methylation in free radical scavenging networks in adult mouse hippocampus following fetal alcohol exposure. PLoS ONE 2016, 11, e0154836. [CrossRef] [PubMed]

167. Perkins, A.; Lehmann, C.; Lawrence, R.C.; Kelly, S.J. Alcohol exposure during development: Impact on the epigenome. Int. J. Dev. Neurosci. 2013, 31, 391-397. [CrossRef] [PubMed]

168. Bekdash, R.A.; Zhang, C.; Sarkar, D.K. Gestational choline supplementation normalized fetal alcohol-induced alterations in histone modifications, DNA methylation, and proopiomelanocortin (POMC) gene expression in beta-endorphin-producing POMC neurons of the hypothalamus. Alcohol. Clin. Exp. Res. 2013, 37, 1133-1142. [CrossRef] [PubMed]

169. Govorko, D.; Bekdash, R.A.; Zhang, C.; Sarkar, D.K. Male germline transmits fetal alcohol adverse effect on hypothalamic proopiomelanocortin gene across generations. Biol. Psychiatry 2012, 72, 378-388. [CrossRef] [PubMed]

170. Subbanna, S.; Nagre, N.N.; Shivakumar, M.; Umapathy, N.S.; Psychoyos, D.; Basavarajappa, B.S. Ethanol induced acetylation of histone at G9a exon1 and G9a-mediated histone H3 dimethylation leads to neurodegeneration in neonatal mice. Neuroscience 2014, 258, 422-432. [CrossRef] [PubMed]

171. Tunc-Ozcan, E.; Ullmann, T.M.; Shukla, P.K.; Redei, E.E. Low-dose thyroxine attenuates autism-associated adverse effects of fetal alcohol in male offspring's social behavior and hippocampal gene expression. Alcohol. Clin. Exp. Res. 2013, 37, 1986-1995. [CrossRef] [PubMed]

172. Gangisetty, O.; Bekdash, R.; Maglakelidze, G.; Sarkar, D.K. Fetal alcohol exposure alters proopiomelanocortin gene expression and hypothalamic-pituitary-adrenal axis function via increasing MeCP2 expression in the hypothalamus. PLoS ONE 2014, 9, e113228. [CrossRef] [PubMed]

173. Portales-Casamar, E.; Lussier, A.A.; Jones, M.J.; MacIsaac, J.L.; Edgar, R.D.; Mah, S.M.; Barhdadi, A.; Provost, S.; Lemieux-Perreault, L.P.; Cynader, M.S.; et al. DNA methylation signature of human fetal alcohol spectrum disorder. Epigenet. Chromatin 2016, 9, 25. [CrossRef] [PubMed]

174. Laufer, B.I.; Kapalanga, J.; Castellani, C.A.; Diehl, E.J.; Yan, L.; Singh, S.M. Associative DNA methylation changes in children with prenatal alcohol exposure. Epigenomics 2015, 7, 1259-1274. [CrossRef] [PubMed]

175. Zhou, F.C.; Balaraman, Y.; Teng, M.; Liu, Y.; Singh, R.P.; Nephew, K.P. Alcohol alters DNA methylation patterns and inhibits neural stem cell differentiation. Alcohol. Clin. Exp. Res. 2011, 35, 735-746. [CrossRef] [PubMed]

176. Laufer, B.I.; Mantha, K.; Kleiber, M.L.; Diehl, E.J.; Addison, S.M.; Singh, S.M. Long-lasting alterations to DNA methylation and ncRNAs could underlie the effects of fetal alcohol exposure in mice. Dis. Models Mech. 2013, 6, 977-992. [CrossRef] [PubMed]

177. Liu, Y.; Balaraman, Y.; Wang, G.; Nephew, K.P.; Zhou, F.C. Alcohol exposure alters DNA methylation profiles in mouse embryos at early neurulation. Epigenetics 2009, 4, 500-511. [CrossRef] [PubMed]

178. Valles, S.; Pitarch, J.; Renau-Piqueras, J.; Guerri, C. Ethanol exposure affects glial fibrillary acidic protein gene expression and transcription during rat brain development. J. Neurochem. 1997, 69, 2484-2493. [CrossRef] [PubMed]

179. Ouko, L.A.; Shantikumar, K.; Knezovich, J.; Haycock, P.; Schnugh, D.J.; Ramsay, M. Effect of alcohol consumption on CpG methylation in the differentially methylated regions of H19 and IG-DMR in male gametes: Implications for fetal alcohol spectrum disorders. Alcohol. Clin. Exp. Res. 2009, 33, 1615-1627. [CrossRef] [PubMed]

180. Masemola, M.L.; van der Merwe, L.; Lombard, Z.; Viljoen, D.; Ramsay, M. Reduced DNA methylation at the PEG3 DMR and KvDMR1 loci in children exposed to alcohol in utero: A south african fetal alcohol syndrome cohort study. Front. Genet. 2015, 6, 85. [CrossRef] [PubMed]

181. Ngai, Y.F.; Sulistyoningrum, D.C.; O’Neill, R.; Innis, S.M.; Weinberg, J.; Devlin, A.M. Prenatal alcohol exposure alters methyl metabolism and programs serotonin transporter and glucocorticoid receptor expression in brain. Am. J. Physiol. Regul. Integr. Comp. Physiol. 2015, 309, R613-R622. [CrossRef] [PubMed]

182. Marjonen, H.; Sierra, A.; Nyman, A.; Rogojin, V.; Grohn, O.; Linden, A.M.; Hautaniemi, S.; Kaminen-Ahola, N. Early maternal alcohol consumption alters hippocampal DNA methylation, gene expression and volume in a mouse model. PLoS ONE 2015, 10, e0124931. [CrossRef] [PubMed] 
183. Veazey, K.J.; Carnahan, M.N.; Muller, D.; Miranda, R.C.; Golding, M.C. Alcohol-induced epigenetic alterations to developmentally crucial genes regulating neural stemness and differentiation. Alcohol. Clin. Exp. Res. 2013, 37, 1111-1122. [CrossRef] [PubMed]

184. Bielawski, D.M.; Zaher, F.M.; Svinarich, D.M.; Abel, E.L. Paternal alcohol exposure affects sperm cytosine methyltransferase messenger RNA levels. Alcohol. Clin. Exp. Res. 2002, 26, 347-351. [CrossRef] [PubMed]

185. Guo, W.; Crossey, E.L.; Zhang, L.; Zucca, S.; George, O.L.; Valenzuela, C.F.; Zhao, X. Alcohol exposure decreases CREB binding protein expression and histone acetylation in the developing cerebellum. PLoS ONE 2011, 6, e19351. [CrossRef] [PubMed]

186. Kleiber, M.L.; Mantha, K.; Stringer, R.L.; Singh, S.M. Neurodevelopmental alcohol exposure elicits long-term changes to gene expression that alter distinct molecular pathways dependent on timing of exposure. J. Neurodev. Disord. 2013, 5, 6. [CrossRef] [PubMed]

187. Subbanna, S.; Shivakumar, M.; Umapathy, N.S.; Saito, M.; Mohan, P.S.; Kumar, A.; Nixon, R.A.; Verin, A.D.; Psychoyos, D.; Basavarajappa, B.S. G9a-mediated histone methylation regulates ethanol-induced neurodegeneration in the neonatal mouse brain. Neurobiol. Dis. 2013, 54, 475-485. [CrossRef] [PubMed]

188. Subbanna, S.; Nagre, N.N.; Umapathy, N.S.; Pace, B.S.; Basavarajappa, B.S. Ethanol exposure induces neonatal neurodegeneration by enhancing CB1R Exon1 histone H4K8 acetylation and up-regulating CB1R function causing neurobehavioral abnormalities in adult mice. Int J. Neuropsychopharmacol. 2014. [CrossRef] [PubMed]

189. Varadinova, M.; Boyadjieva, N. Epigenetic mechanisms: A possible link between autism spectrum disorders and fetal alcohol spectrum disorders. Pharmacol. Res. 2015, 102, 71-80. [CrossRef] [PubMed]

190. Tyler, C.R.; Allan, A.M. Prenatal alcohol exposure alters expression of neurogenesis-related genes in an ex vivo cell culture model. Alcohol 2014, 48, 483-492. [CrossRef] [PubMed]

191. Gressens, P.; Lammens, M.; Picard, J.J.; Evrard, P. Ethanol-induced disturbances of gliogenesis and neuronogenesis in the developing murine brain: An in vitro and in vivo immunohistochemical and ultrastructural study. Alcohol Alcohol. 1992, 27, 219-226. [PubMed]

192. Miller, M.W.; Robertson, S. Prenatal exposure to ethanol alters the postnatal development and transformation of radial glia to astrocytes in the cortex. J. Comp. Neurol. 1993, 337, 253-266. [CrossRef] [PubMed]

193. Rubert, G.; Minana, R.; Pascual, M.; Guerri, C. Ethanol exposure during embryogenesis decreases the radial glial progenitorpool and affects the generation of neurons and astrocytes. J. Neurosci. Res. 2006, 84, 483-496. [CrossRef] [PubMed]

194. Ryan, S.H.; Williams, J.K.; Thomas, J.D. Choline supplementation attenuates learning deficits associated with neonatal alcohol exposure in the rat: Effects of varying the timing of choline administration. Brain Res. 2008, 1237, 91-100. [CrossRef] [PubMed]

195. Thomas, J.D.; Biane, J.S.; O’Bryan, K.A.; O’Neill, T.M.; Dominguez, H.D. Choline supplementation following third-trimester-equivalent alcohol exposure attenuates behavioral alterations in rats. Behav. Neurosci. 2007, 121, 120-130. [CrossRef] [PubMed]

196. Rastegar, M.; Hotta, A.; Pasceri, P.; Makarem, M.; Cheung, A.Y.; Elliott, S.; Park, K.J.; Adachi, M.; Jones, F.S.; Clarke, I.D.; et al. MECP2 isoform-specific vectors with regulated expression for rett syndrome gene therapy. PLoS ONE 2009, 4, e6810. [CrossRef] [PubMed]

197. Zhang, X.; Bhattacharyya, S.; Kusumo, H.; Goodlett, C.R.; Tobacman, J.K.; Guizzetti, M. Arylsulfatase B modulates neurite outgrowth via astrocyte chondroitin-4-sulfate: Dysregulation by ethanol. Glia 2014, 62, 259-271. [CrossRef] [PubMed]

198. Pascual, M.; Guerri, C. The peptide NAP promotes neuronal growth and differentiation through extracellular signal-regulated protein kinase and akt pathways, and protects neurons co-cultured with astrocytes damaged by ethanol. J. Neurochem. 2007, 103, 557-568. [CrossRef] [PubMed]

199. Kleiber, M.L.; Laufer, B.I.; Stringer, R.L.; Singh, S.M. Third trimester-equivalent ethanol exposure is characterized by an acute cellular stress response and an ontogenetic disruption of genes critical for synaptic establishment and function in mice. Dev. Neurosci. 2014, 36, 499-519. [CrossRef] [PubMed]

200. Subbanna, S.; Basavarajappa, B.S. Pre-administration of G9a/GLP inhibitor during synaptogenesis prevents postnatal ethanol-induced LTP deficits and neurobehavioral abnormalities in adult mice. Exp. Neurol. 2014, 261, 34-43. [CrossRef] [PubMed] 
201. Rogic, S.; Wong, A.; Pavlidis, P. Meta-analysis of gene expression patterns in animal models of prenatal alcohol exposure suggests role for protein synthesis inhibition and chromatin remodeling. Alcohol. Clin. Exp. Res. 2016, 40,717-727. [CrossRef] [PubMed]

202. Henikoff, S.; Shilatifard, A. Histone modification: Cause or cog? Trends Genet. 2011, 27, 389-396. [CrossRef] [PubMed]

203. Badeaux, A.I.; Shi, Y. Emerging roles for chromatin as a signal integration and storage platform. Nat. Rev. Mol. Cell Biol. 2013, 14, 211-224. [CrossRef] [PubMed]

204. Coles, C.D.; Kable, J.A.; Keen, C.L.; Jones, K.L.; Wertelecki, W.; Granovska, I.V.; Pashtepa, A.O.; Chambers, C.D.; CIFASD. Dose and timing of prenatal alcohol exposure and maternal nutritional supplements: Developmental effects on 6-month-old infants. Matern. Child Health J. 2015, 19, 2605-2614. [CrossRef] [PubMed]

205. Nguyen, T.T.; Risbud, R.D.; Mattson, S.N.; Chambers, C.D.; Thomas, J.D. Randomized, double-blind, placebo-controlled clinical trial of choline supplementation in school-aged children with fetal alcohol spectrum disorders. Am. J. Clin. Nutr. 2016, 104, 1683-1692. [CrossRef] [PubMed]

206. Schneider, R.D.; Thomas, J.D. Adolescent choline supplementation attenuates working memory deficits in rats exposed to alcohol during the third trimester equivalent. Alcohol. Clin. Exp. Res. 2016, 40, 897-905. [CrossRef] [PubMed]

(C) 2017 by the authors. Licensee MDPI, Basel, Switzerland. This article is an open access article distributed under the terms and conditions of the Creative Commons Attribution (CC BY) license (http:/ / creativecommons.org/licenses/by/4.0/). 